PONTIFÍCIA UNIVERSIDADE CATÓLICA DO RIO DE JANEIRO

\title{
Experiência em shopping center: \\ O que a Geração Z espera deste empreendimento no Rio de Janeiro
}

Isabela Porto

Trabalho de Conclusão de Curso

Centro de CIÊnCIAS Socials - CCS

DePARTAMENTO de AdMINISTRAÇÃo

Graduação em Administração de Empresas 
Isabela Porto

\section{Experiência em shopping center:}

O que a Geração Z espera deste empreendimento no Rio de Janeiro

Trabalho de Conclusão de Curso

Trabalho de Conclusão de Curso, apresentado ao programa de graduação em Administração da PUC-Rio como requisito parcial para a obtenção do titulo de graduação em Administração.

Orientador(a) : Paula Cunha

Rio de Janeiro,

junho de 2018. 


\section{Agradecimentos}

Dedico o presente trabalho à minha mãe Marcia, minha irmã Laura e às amigas que fiz no curso de Administração. Minha mãe foi, com certeza, quem mais me incentivou a estudar e me dedicar a minha vida acadêmica ao longo dos quatro anos de curso. Gostaria também de dedicar o meu trabalho aos excelentes professores que tive no colégio Santo Agostinho e na faculdade PUC-Rio, por terem contribuído não só para a minha formação acadêmica, mas também para minha formação como cidadã. Agradecimento especial à professora Paula Cunha, que com toda sua experiência na área de Marketing e capacidade como profissional, me orientou ao longo do meu período de conclusão da graduação. 


\section{Resumo}

Porto, Isabela. Experiência em shopping center: $O$ que a geração $Z$ espera deste empreendimento no Rio de Janeiro. Rio de Janeiro, 2018. Número de páginas: 47. Trabalho de Conclusão de Curso - Departamento de Administração. Pontifícia Universidade Católica do Rio de Janeiro.

O presente estudo visa analisar quais aspectos são percebidos pela geração $Z$ como essenciais durante a experiência em um shopping center. A pesquisa foi realizada exclusivamente com integrantes da Geração Z, residentes no estado do Rio de Janeiro e que frequentam shoppings centers. Para o presente estudo, foi realizada uma pesquisa qualitativa através de entrevistas em profundidade realizadas em shoppings e na Universidade PUC-Rio. Objetivou-se, com isso, avaliar quais as principais motivações e principais barreiras que esta geração transformacional apresenta em relação a experiência em um shopping center com a finalidade de atrair mais jovens para estes empreendimentos no estado do Rio de Janeiro.

Palavras-chave: Marketing, Comportamento do Consumidor, Shopping, Geração Z, Millenials, Experiência do Consumidor, Entretenimento, Varejo, Lazer.

\section{Abstract}

Porto, Isabela. Mall Experience: What Gen Z expects from the shopping malls in Rio de Janeiro. Rio de Janeiro, 2018. Number of pages: 47. Course Completion Work - Administration Department. Pontifical Catholic University of Rio de Janeiro.

The present study aims to analyze which aspects are perceived by the generation $Z$ as essential during the experience in a shopping mall. The survey was conducted exclusively with consumers from the Generation Z, residents in the state of Rio de Janeiro and that frequent malls. For the present study, a qualitative research was conducted through in-depth interviews in shopping malls in the North Zone of Rio de Janeiro and PUC-Rio University. The objective was to evaluate the main motivations and main barriers that this transformational generation presents in relation to the experience in a shopping mall. The purpose is to attract more young people to these centers in the state of Rio de Janeiro.

Key-words: Marketing, Consumer Behavior, Shopping, Gen Z, Millenials, Customer Experience, Entertainment, Retail, Leisure. 


\section{Sumário}

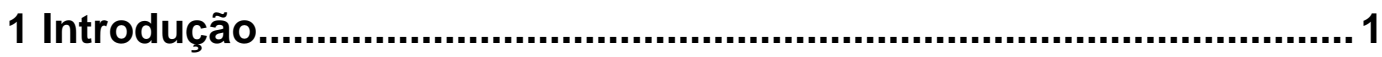

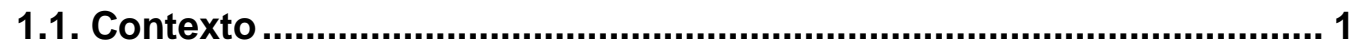

1.2. Situação Problema............................................................................. 3

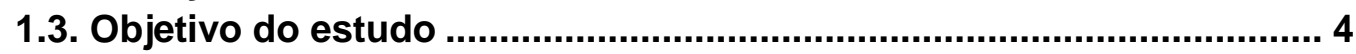

1.4. Objetivos intermediários ................................................................... 4

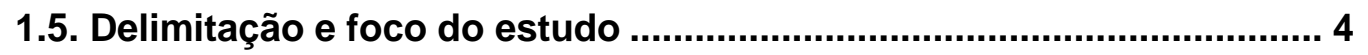

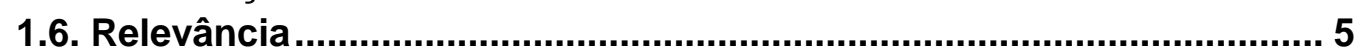

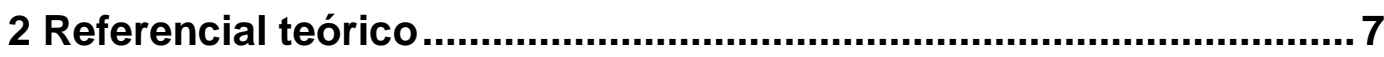

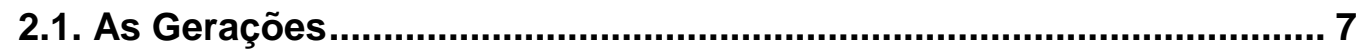

2.1.1. Gerações versus Coortes............................................................. 7

2.1.2. As Gerações e principais características........................................... 8

2.1.3. A Geração Z (1995 a 2010)........................................................ 10

2.2. Perfil socioeconômico dos jovens brasileiros .................................... 17

2.3. O Comportamento de consumo da Geração $Z$................................... 18

2.4. Experiência do Consumidor nos Shopping Centers .......................... 20

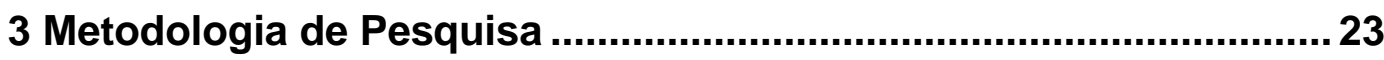

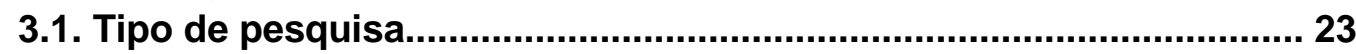

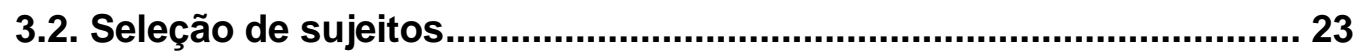

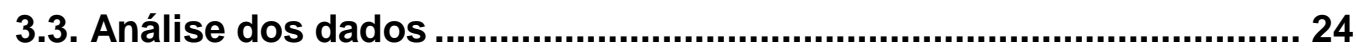

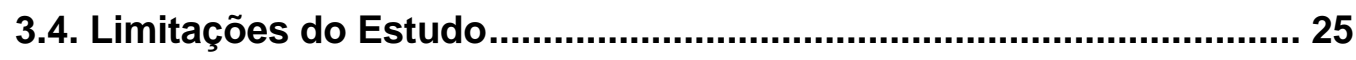

4 Apresentação e análise de resultados ...........................................26

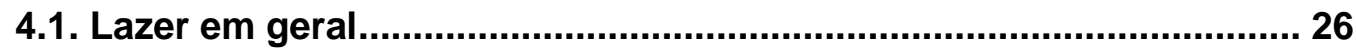

4.2. Lazer em shopping ....................................................................... 27

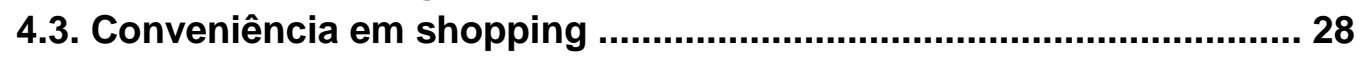

4.4. Experiência nos shoppings frequentados ...................................... 29

4.5. Características essenciais aos shoppings ........................................ 33

4.6. Shopping como lugar de encontrar e estar com pessoas .................. 34

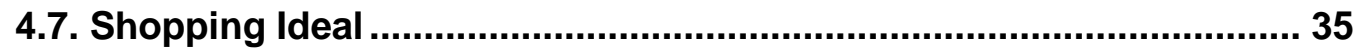

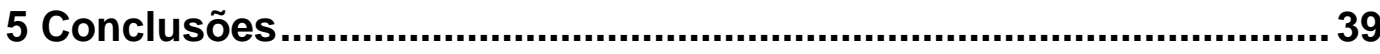

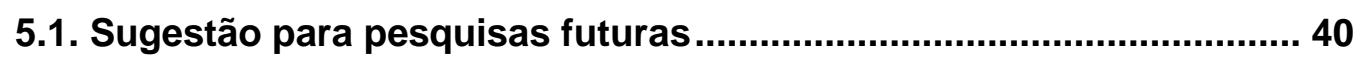

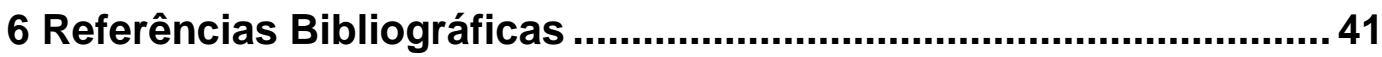

7 Anexo: Roteiro para a entrevista em profundidade :........................ 46 


\section{Lista de Figuras:}

Figura 1 - O Histórico das Gerações. Fonte: KOJIKOVSKI, 2017.............9

Figura 2 - Consumo de produtos que sofrem a influência dos jovens.

Fonte: JWT Intelligence (2012 apud PUIU, 2016).......................11

Figura 3 - Diferenças das preferências de comunicação entre as

gerações. Fonte: Van den Bergh, J. (2015 apud PUIU, 2016). ......... 15

Figura 4 - Distribuição dos jovens entre as cinco regiões brasileiras.

Fonte: IBGE/SIS (2015 apud BRETAS, 2016).

\section{Lista de Tabelas:}

Tabela 1 - Perfil dos entrevistados. Elaborado pela autora, 2018. 24 


\section{Introdução}

\subsection{Contexto}

O Shopping Center, apesar de parecer um conceito moderno, surgiu desde os primeiros relatos da história como um espaço de compras e interação entre indivíduos de uma sociedade. O seu nascimento veio da necessidade de conveniência do homem em poder adquirir e resolver tudo em um único local que fosse de fácil acesso, sendo esta lógica ainda a fundamental para o desenvolvimento da indústria no contexto atual (SEMMA GROUP, 2012).

No Brasil, a indústria de Shopping Center surgiu formalmente no ano de 1966, a partir da inauguração do Shopping Center Iguatemi, na cidade de São Paulo. As suas instalações inovadoras à época fizeram com que a população ao redor reprovasse este conceito moderno. Com isso, a rotatividade das lojas era alta e o retorno financeiro era baixo, evidenciando que os consumidores ainda não estavam preparados para este novo modo de consumo (SEMMA GROUP, 2012).

A indústria nacional de shoppings começou a ser aceita, mesmo que aos poucos, a partir da década de 70 , com a inauguração de oito novos empreendimentos, influenciando fortemente os hábitos de consumo de milhares de brasileiros. Com o desenvolvimento urbano na década de 80 , houve 0 planejamento e desenvolvimento de novos projetos a fim de expandir a indústria que vinha se mostrando atrativa, tanto para investidores como para os empreendedores. A década de 80 pode ser conhecida como o período de maturação do mercado de shoppings no país, na medida em que passaram a se inserir no cotidiano dos consumidores brasileiros. No final deste período, o país contava com 56 shoppings centers reconhecidos pela Associação Brasileira de Shoppings Centers (ABRASCE), sem levar em consideração os demais projetos de menor proporção em funcionamento (SEMMA GROUP, 2012).

A década de 90 pode ser caracterizada como turbulenta para a indústria devido ao momento econômico desfavorável do país, exigindo maior eficiência e assertividade nas decisões dos empresários. Neste período, os shoppings foram sustentados principalmente pelas marcas e fabricantes que souberam apresentar 
a melhor relação "preço - produto - nome", criando um branding de valor para o cliente (SEMMA GROUP, 2012). De acordo com o sócio diretor da GS\&BW, Luiz Alberto Marinho (2014), os shoppings voltaram a crescer após o período de crise e dificuldade de consumo da década de 90, principalmente por conta do aumento do poder de compra do consumidor na época (MERCADO\&CONSUMO, 2014).

Entre 1966 e 2006, uma janela de tempo de 40 anos, foram inaugurados 351 shoppings centers no Brasil. Entre 2007 e 2013, porém, o número de empreendimentos saltou para 497, apresentando um crescimento de aproximadamente $50 \%$, sem considerar as expansões que elevaram a área bruta locável destes centros. (MERCADO\&CONSUMO, 2014).

Atualmente, o país conta com 571 shoppings centers reconhecidos pela ABRASCE (2018), com previsão de inauguração de mais 23 shoppings este ano. Muito mais do que centros de compras, os shoppings representam centros de lazer e entretenimento no dia-a-dia dos brasileiros. Apesar do cenário econômico desfavorável para o varejo nacional, no qual o setor apresentou queda de 6,5\% em vendas até outubro de 2016 segundo o IBGE (2016), a indústria de shoppings centers cresceu $4,3 \%$, demonstrando seu elevado potencial de desenvolvimento futuro (ABRASCE, 2017).

Uma pesquisa realizada pelo IBOPE Inteligência em 2016 levantou o conceito de shopping como centro de lazer e entretenimento, demonstrando que $55 \%$ da motivação dos brasileiros em visitar shoppings era o lazer (37\% para passear e ver amigos e 18\% para comer) e apenas 34\% era o consumo. Em 1998, a proporção era bem diferente: $46 \%$ dos brasileiros iam para comprar e $26 \%$ iam para ter um momento de lazer. Outra descoberta importante da pesquisa foi que apesar de os brasileiros estarem passando mais tempo dentro dos shoppings, estão entrando em menos lojas, demonstrando maior exigência em relação à atratividade das marcas (DEARO, 2016).

Se os brasileiros do início do milênio tinham prazer em comprar, sendo o Brasil o primeiro no ranking de consumo, vide pesquisa feita por Rubens (2003 apud CERETTA e FROEMMING, 2011), os brasileiros de hoje priorizam o lazer e entretenimento (ABRASCE, 2018). 


\subsection{Situação Problema}

De acordo com o especialista em shopping center, Michel Cutait (2015), o motivo existencial do shopping é o de atender as necessidades do consumidor. Portanto, é essencial que os profissionais por trás das administradoras de shoppings conheçam profundamente o comportamento de compra e desejos destes consumidores, colocando-os no centro de suas decisões (CUTAIT, 2015).

Bloch et al (1994) constataram que os consumidores tinham uma visão ampliada de shopping. Além de um ambiente de compra, consideravam um lugar de entretenimento. Em tempos de crise e crescimento do e-commerce no Brasil, a pesquisa realizada pelo Instituto Officina Sophia em 2016 com brasileiros de 14 a 18 anos confirmou esta afirmação. O resultado apontou que somente $16 \%$ dos jovens vão ao shopping para fazer compras, enquanto $80 \%$ destes jovens dizem ir ao shopping para vivenciar momentos de lazer, dentre eles: assistir um filme no cinema (30\%), passear com a família (19\%), fazer refeições (16\%) e passear com amigos (15\%) (MUNDO DO MARKETING, 2017). Sendo assim, o shopping pode ser enxergado como life center pelos jovens brasileiros. Se compararmos com outros países da América Latina, em média 31\% dos jovens vão ao shopping para fazer compras, demonstrando a diferença nos hábitos de lazer e consumo dos brasileiros (MENDONÇA, 2017).

Se por um lado os jovens veem o shopping como espaço de convivência e lazer, por outro, a indústria não parece suprir as necessidades dessa nova geração, que busca experiências diferenciadas nos centros de compra. De acordo com a ABRASCE (2017), 72\% do total das lojas em shoppings no Brasil são satélites, ou seja, lojas que vendem itens de vestuário, calçados, acessórios, artigos do lar, telefonia e diversos. Apenas $12 \%$ do total são restaurantes (com ou sem serviço) e $3 \%$ são salas de cinema, demonstrando ainda a carência destes empreendimentos em oferecer opções diferenciadas de lazer e entretenimento para atender as demandas das novas gerações (ABRASCE, 2017).

Enxergando esta onda comportamental de mudanças nos hábitos das novas gerações de consumidores, a indústria vem buscando se adaptar, ampliando a concepção de shopping não somente como espaço de compras. A pesquisa do IBOPE Inteligência em 2016 (DEARO, 2016) apontou, por exemplo, que os shoppings projetados no design antigo destinam $8 \%$ do seu espaço para alimentação, mas que os mais novos dedicam 17\% de sua área (DEARO, 2016). A pesquisa "Shopping do Futuro", realizada pela consultoria de tendências WGSN em 2016 e divulgada pela ABRASCE (2017), apontou também que os 
empreendimentos estão buscando atender esta nova geração de consumidores através da oferta de espaços de convivência, ambientes verdes, wifi gratuito, games interativos, shows e cinema com óculos de realidade virtual (OLIVEIRA, 2017).

\subsection{Objetivo do estudo}

O objetivo deste estudo é entender quais são as expectativas e preferências dos jovens da geração $Z$ em termos de experiências, entretenimento, serviços e mix de lojas nos shoppings centers do Rio de Janeiro.

\subsection{Objetivos intermediários}

Para alcançar o objetivo final desse trabalho, os objetivos intermediários a serem obtidos são:

- Identificar quais são as características da geração Z que influenciam o seu comportamento de consumo;

- Identificar quais tendências mundiais estão impactando a forma de consumir destes jovens;

- Identificar quais são as barreiras que levam os consumidores a não frequentarem ou evitarem experiências em shoppings.

\subsection{Delimitação e foco do estudo}

O estudo será limitado especificamente para integrantes da geração Z, definida como as pessoas nascidas entre 1995 e 2010 (KOJIKOVSKI, 2017), de todas as classes sociais, moradores do Rio de Janeiro e o período analisado será o primeiro semestre de 2018. Outros perfis que não sejam este apresentado não serão abordados.

O presente trabalho está delimitado a entender quais as características dessa geração Z, e como elas influenciam suas percepções e expectativas em relação à experiência de consumo em shoppings.

Não é escopo deste estudo: abordar a visão das empresas com relação a este assunto, mensurar resultados financeiros, elaborar soluções ou estratégias aos executivos das empresas, nem levantar modelos de gestão. Sendo assim, o estudo se centra na percepção dos consumidores. 


\subsection{Relevância}

A geração Z, objeto de estudo do trabalho, começa agora a ser estudada e tornar-se assunto de interesse dos departamentos de Marketing e Recursos Humanos, pois representa um novo e jovem consumidor, cujos hábitos, valores, crenças e preferências estão em formação e consolidação. (KOJIKOVSKI, 2017).

Blakley (2016 apud PUIU, 2016) afirma que em 2020, a Geração Z representará cerca de $40 \%$ dos consumidores e a atenção dos profissionais de marketing deve ser focada nessa faixa de idade. Hoje, esse grupo já representa cerca de $26 \%$ da população mundial e somente no Brasil somariam 30 milhões de pessoas importantes por seu poder de compra e influência (KOJIKOVSKI, 2017). Segundo a psicóloga americana Kit Yarrow (2017), especialista em consumo e autora de livros como "Geração compra: como os jovens estão revolucionando o varejo":

A sociedade valoriza cada vez mais a juventude sobre a sabedoria. Os pais dessa geração estão mais próximos e se identificam mais com os filhos do que as gerações anteriores. Os Zs, portanto, já nascem com um poder de influência enorme. (Trecho de entrevista de Kit Yarrow em KOJIKOVSKI, 2017).

Além da relevância exercida por estes novos consumidores, a indústria de shoppings centers apresenta um peso muito forte na economia do país. De acordo com a ABRASCE (2017), gera mais de um milhão de empregos formais e recebe mais de 438 milhões de pessoas mensalmente. Não obstante, o faturamento anual da indústria em 2017 foi de $\mathrm{R} \$ 167,7$ bilhões, com um crescimento de 6,2\% em relativo a 2016. Estima-se que isso represente 19\% de participação das vendas no varejo (DEARO, 2017).

Se o setor varejista já deve estar atento às novas tendências apresentadas pelos consumidores, também deve estar atento ao impacto que a crise econômica brasileira traz ao seu desempenho. Isso porque, é um dos primeiros a sentir os impactos causados por mudanças na conjuntura econômica, uma vez que suas vendas são sensíveis ao nível de renda do consumidor, desemprego, juros, condições e prazos de financiamento ao cliente. Outras barreiras são a elevada concorrência e inadimplência (DEPEC, 2018).

Diante deste cenário, é essencial entender o que as novas gerações esperam do mercado de shoppings, tão representativo na economia brasileira. $\mathrm{O}$ 
presente trabalho buscará, portanto, contribuir para a exploração deste momento de transição, apresentando e cruzando informações a fim de fomentar o debate das questões contemporâneas da indústria de shoppings centers. 


\section{Referencial teórico}

\subsection{As Gerações}

De acordo com Schiffman e Kanuk (2000), os jovens, mercado em crescimento e composto pelos futuros consumidores, têm alto poder de influência pelos seguintes motivos: além de gastarem muito dinheiro, gastam o dinheiro da família, influenciam nas suas compras e propagam tendências, revolucionando a moda de diversos produtos. Sendo assim, as empresas concentram grande parte de seus investimentos buscando a melhor maneira de se comunicar, atrair e comercializar para os Millenials, dos jovens nascidos entre 1980 e 1994. (KOJIKOVSKI, 2017).

Por terem crescido junto ao "boom" da Internet, os Millennials (1980-94) transformaram a forma de consumo e trabalho, criando desafios para as empresas. Algumas das características marcantes desses jovens são: estão sempre online, são questionadores, valorizam a experiência e o desenvolvimento sustentável. Porém, investir somente em atrair os Millenials hoje já é ultrapassado, pois o centro das atenções para as empresas será a geração Z, dos nascidos entre 1995 e 2010. (KOJIKOVSKI, 2017).

\subsubsection{Gerações versus Coortes}

Apesar de o conceito de geração ser mais disseminado entre as empresas, ele é também criticado por alguns autores, que defendem o conceito de Coortes, altamente influenciado pelos eventos externos que ocorreram quando os jovens estavam em fase de amadurecimento. Coortes são grupos de indivíduos que nascem durante o mesmo período e vivenciam eventos semelhantes durante 0 final da adolescência / início da vida adulta (geralmente entre seus 17 e 23 anos). (SCHEWE, MEREDITH e NOBLE, 2000).

Esses eventos podem ser de origem social, política ou econômica, e definem os valores, crenças, preferências, atitudes e comportamentos de consumo desse grupo de forma mais duradoura, perdurando por toda a vida. Não 
sendo definidos por um período fixo de anos, esses coortes podem cobrir um período curto de anos como no caso do Coorte americano da II Guerra Mundial, que durou somente seis anos. (SCHEWE, MEREDITH e NOBLE, 2000).

O conceito de coortes trata a forma de gastar e economizar de forma muito diferente, o que influencia no comportamento de consumo do grupo. Por exemplo, o coorte dos que entraram no mercado de trabalho durante a Grande Depressão, com idade entre 79 e 88 anos, é composto por indivíduos conservadores com relação ao dinheiro. Isso porque eles viveram tempos de crise econômica, evitando, portanto, riscos econômicos. Ao contrário destes, as pessoas com idade 55 a 78 anos, influenciadas pela Depressão, também vivenciaram os tempos áureos do pós-guerra, sendo mais arrojados quando o assunto é gastar dinheiro. (SCHEWE, MEREDITH e NOBLE, 2000).

Por essa definição de coorte, como se trata de um grupo amplo de jovens entre 8 e 23 anos, o que é denominado de Geração Z, poderia compor mais de um coorte pois parte deles estaria experimentando esses eventos no presente momento (aqueles na faixa mais alta, entre 17 e 23) e outros ainda teriam muitos anos à frente para estabelecerem seus valores e atitudes. (SCHEWE, MEREDITH e NOBLE, 2000).

Mesmo assim, os coortes geracionais não são grupos considerados no momento da construção da estratégia de marketing, enquanto poderiam ser uma ferramenta para segmentar mercados e criar ações de promoção da empresa. (SCHEWE, MEREDITH e NOBLE, 2000).

\subsubsection{As Gerações e principais características}

Diferentemente do coorte, a geração, conceito mais estudado pelas empresas, é definida apenas pelo ano de nascimento do indivíduo. (SCHEWE, MEREDITH e NOBLE, 2000). Abaixo, podemos observar as características principais das últimas quatro gerações estudadas pelas empresas. (Fonte: KOJIKOVSKI, 2007). 
Figura 1 - O Histórico das Gerações. Fonte: KOJIKOVSKI, 2017.

\section{O HISTÓRICO DAS GERAÇ̃̃ES}

0 contexto histórico da criação de cada geração influencia seu comportamento e sua forma de consumir
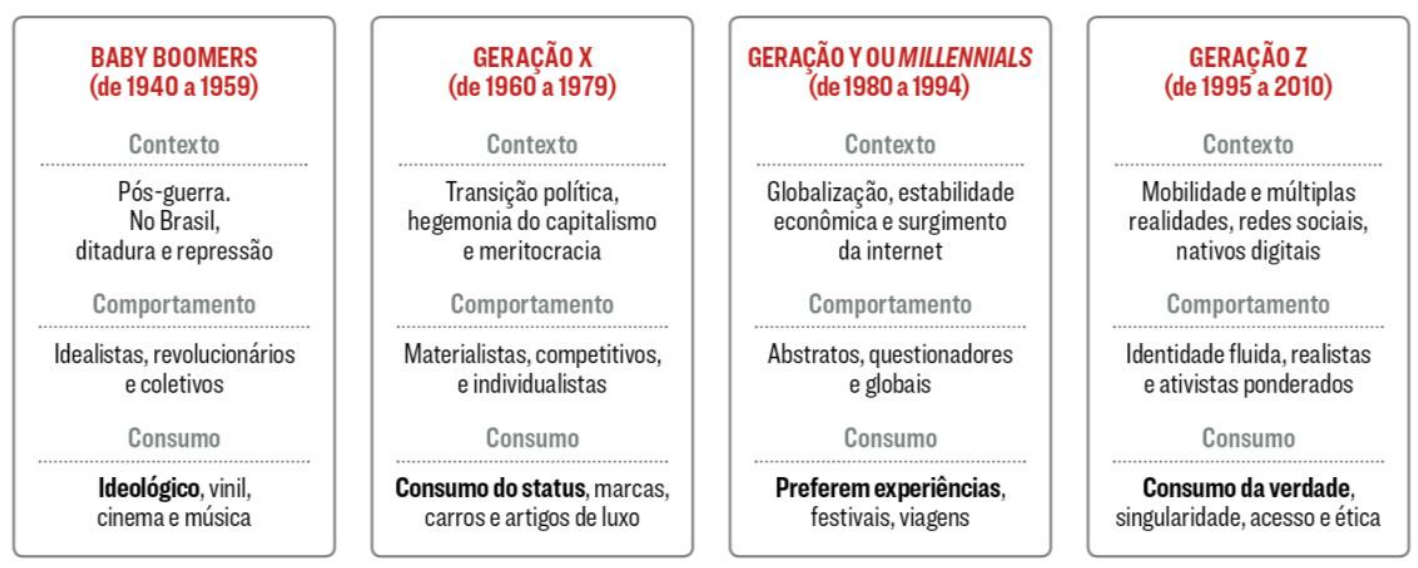

A geração dos Baby Boomers representa as pessoas nascidas entre 1940 e 1959, durante e após a Segunda Guerra Mundial. Devido ao contexto de pós-guerra, ditadura e repressão no Brasil, esse grupo apresenta um comportamento idealista, revolucionário e coletivo. Costumam gastar seu dinheiro em busca de bens que os tragam felicidade (KOJIKOVSKI, 2017; TRENDS EMAGAZINE, 2017).

A Geração X, por sua vez, é dos nascidos entre 1960 a 1979, em um contexto de mudanças politicas, domínio capitalista e meritocracia no Brasil. Mundialmente falando, foram individuos que cresceram no mal-estar dos anos 1970 após a Guerra do Vietnã e Watergate. Por isso, tendem a ser materialistas e aspiram artigos de luxo (KOJIKOVSKI, 2017; TRENDS EMAGAZINE, 2017).

A Geração Y, também conhecida como os Millennials, nasceu de 1980 a 1994, experienciando eventos marcantes como os atentados terroristas de 11 de setembro e os colapsos em 2000 e 2008, além do surgimento da Internet e globalização. Este grupo, em grande parte, têm evitado despesas financeiras e compromissos como o de possuir carros e casas. De acordo com o Departamento do Trabalho dos EUA, dois terços deles alugam suas casas, além de ser a geração com o menor número de carros comprados (KOJIKOVSKI, 2017; TRENDS EMAGAZINE, 2017).

Por fim, a geração Z, que será aprofundada neste trabalho, é a dos nascidos entre 1995 e 2010, representando, portanto, um grupo de nativos digitais. (KOJIKOVSKI, 2017) 
O estudo realizado pela Grail Research em $2011^{1}$ (PUIU, 2016) também aponta a existência da geração Alpha, nascida após o ano de 2010. "Esta geração será ainda mais dependente tecnologia do que a Geração Z. Assim, as empresas terão que manter o ritmo acelerado destas novas gerações e investir mais dinheiro em pesquisa e desenvolvimento, porque mais produtos inovadores aparecerão diariamente." (PUIU, 2016).

\subsubsection{A Geração Z (1995 a 2010)}

Falando especificamente sobre a geração Z, objeto de estudo do trabalho, vemos que ela começa a tornar-se foco dos acadêmicos por representar um consumidor cuja individualidade está em formação e consolidação.

Esta geração tem datas de início diferentes dependendo da fonte. Algumas delas colocam no início de 1990 (TULGAN, 2013; GRAIL RESEARCH, 2011), outras em meados dos anos 90 (NIRSA 2013; SEEMILLER E GRACE, 2013; SLADEK E GRABINGER, 2014; BERKUP, 2014; ADECCO, 2015) ou mesmo no início de 2000 (muitas fontes colocam a data de início entre meados dos anos 90 e início de 2000). (PUIU, 2016)

Estima-se que a geração $Z$ atualmente represente cerca de $26 \%$ da população mundial e 30 milhões de pessoas no Brasil (KOJIKOVSKI, 2017). Além da representatividade em número de indivíduos, estes jovens tem elevado poder de influência na compra de produtos para casa, conforme já havia levantado por Schiffman e Kanuk (2000). Abaixo, é possível identificar os produtos que os pais da Geração X sofrem influência dos seus filhos no momento da compra, segundo um estudo realizado ${ }^{2}$ pela JWT Intelligence em 2012 e citado por PUIU (2016). Podemos observar que as categorias de produtos que destacam-se são: os brinquedos, com $84 \%$ das mães afirmando que sofrem influência de seus filhos, roupas com $74 \%$ e o menu de jantar da semana com $73 \%$.

\footnotetext{
1 Consumers of Tomorrow Insights and Observations About Generation Z, November 2011. Disponível em: www.integreon.com/pdf/Blog/Consumers_of_Tomorrow_Insights_and_Observations_Abo ut_Generation_Z_246.pdf

${ }^{2}$ Meet Generation Z: Forget everything you learned about Millennials. Disponível em: https://it-szkola.edu.pl/upload/files/PokolenieZJakieJest.pdf
} 


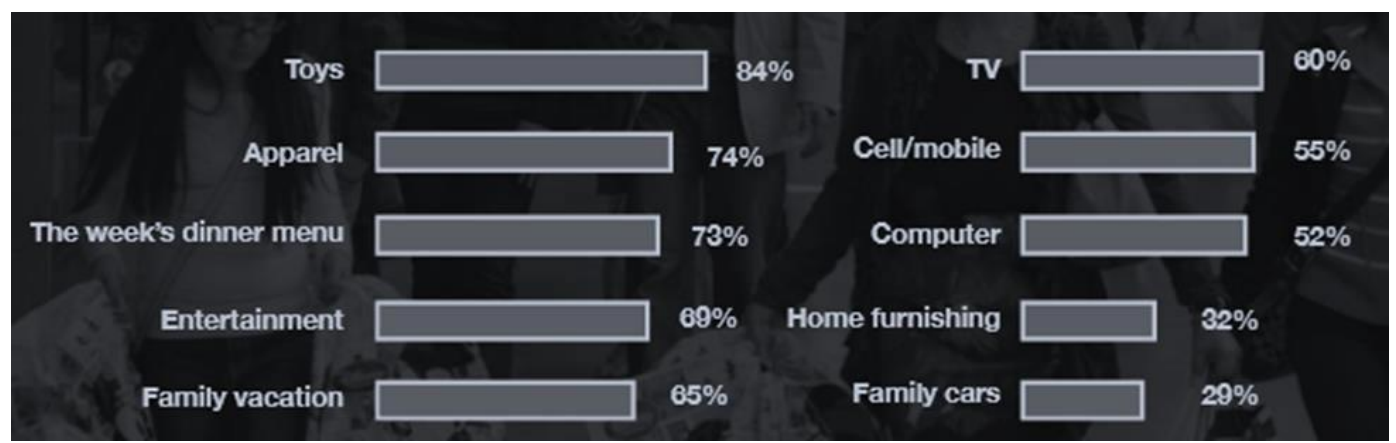

Figura 2 - Consumo de produtos que sofrem a influência dos jovens. Fonte: JWT Intelligence (2012 apud PUIU, 2016).

Apesar de influenciar fortemente a decisão de compra de seus pais, a Geração Z tem características, preferências, ideias e comportamentos bem distintos de seus pais e peculiares a esta geração. Primeiramente, eles são muito influenciados pela tecnologia, passando grande parte do seu tempo online e fazendo uso de produtos de inovação tecnológica. (PUIU, 2016).

Wood (2013, apud PUIU, 2016) caracteriza este grupo de jovens em quatro tendências que os personifica:

- Foco em inovação: eles sabem todas as novidades do mercado e querem testar antes dos outros.

- Conveniência: a Geração Z quer se sentir confortável e ter 0 produto que eles querem, preservando sua privacidade.

- A segurança ou o desejo de se sentir seguro fazem com que os membros da Geração Z vivam sob estilo de vida esperado.

- Escapismo, significando o desejo de escapar da pressão e do estresse da atualidade. (WOOD, 2013 apud PUIU, 2016).

Complementando esta análise, Tapscott (2010) acredita que a Geração Z pode ser sintetizada em oito características fundamentais, algumas destas contraditórias às de Wood:

- Busca pela liberdade em tudo o que faz: tanto para experimentar coisas novas, como no próprio ambiente de trabalho. Ele afirma que "os jovens insistem na liberdade de escolha". (TAPSCOTT, 2010, p. 95). Meir (2018) aponta que é uma geração que quer sair o quanto antes da casa dos pais para serem livres.

- Costume de personalizar tudo a sua volta: os produtos, as experiências de consumo, a mídia, rejeitando também a padronização de cargos de trabalho. 
Um estudo ${ }^{3}$ da Ernst \& Young de 2015 (PUIU, 2016) reforça esta característica: estes jovens valorizam menos os cartões, promoções, eventos e programas de fidelidade tradicionais e, em contrapartida, se sentem mais atraídos por produtos que possam ser customizados e personalizados online.

- Curiosidade de investigar e checar as informações, considerando natural pesquisar tudo a respeito da empresa e produto antes de consumi-lo.

- Integridade, certificando-se de que os valores da empresa estão alinhados com seus valores como indivíduo. Esta característica está relacionada a lealdade e transparência que estes jovens esperam das organizações, tanto das que trabalham como das que consomem. Para o autor, entretanto, pode parecer um pouco contraditório após a onda de denúncias de trabalho escravo feitas às grandes marcas de moda, que não tiveram seu crescimento abalado e não perderam clientes.

- Colaboração e relacionamento, sobretudo nos canais virtuais (Facebook, MySpace), nos quais os jovens colaboram com opiniões acerca de produtos e serviços e criam comunidades que incentivam o trabalho em conjunto.

- Entretenimento associado ao trabalho, educação e vida social, devido ao crescimento em meio a experiências interativas e busca em fazer o que ama por parte do jovem. Esse fator cria demandas também para as empresas que queiram atender a esta geração, tanto na oferta de trabalho como na oferta de produtos e serviços. No caso de produtos, a diversão exerce papel tão importante quanto à funcionalidade do mesmo.

- Velocidade, uma expectativa inerente à geração por ter nascido em uma era dinâmica e digital, acostumada a receber respostas instantâneas. Com isso, estes jovens esperam a mesma agilidade ao consumir um produto e/ou serviço: tanto nas respostas, como na entrega. Esta ansiedade reflete também no plano de carreira deste grupo, que tem a esperança de crescer rapidamente dentro de uma organização.

- Inovação: esta geração deseja produtos inovadores e modernos por trazer uma autoimagem positiva e status social. Com isso, a inovação deve ser realtime, seguindo a cultura da invenção.

Jason Jennings (2017), por sua vez, sintetiza a geração também em oito características apresentadas por outros cientistas geracionais:

\footnotetext{
${ }^{3}$ EY. Americas Retail Report: Redefining loyalty for retail. June 2015. Disponível em: $<$ www.ey.com/Publication/vwLUAssets/EY-americas-retail-report- june-2015/\$FILE/EYamericas-retail-report-june-2015.pdf>
} 
- Os membros da Geração Z são realistas e não idealizam as coisas. Por exemplo, Eles sabem que os planos de aposentadoria nem sempre
se concretizam. (JENNINGS, 2017).

$12 \%$ destes jovens já começaram a pensar e a poupar para a sua aposentadoria, 35\% pensam em se aposentar a partir de 20 anos e $25 \%$ trabalham meio período para poupar dinheiro (MEIR, 2018).

- Ao contrário de Tapscott (2010), Jennings (2017) defende que este grupo prefere a privacidade, buscando mídias sociais em que suas mensagens não possam ser detectadas e desapareçam em questão de segundos, como é o caso do Snapchat e Whisper. O Facebook já fica para trás nessa geração, por ser uma mídia social mais pública. Essa privacidade se reflete também no ambiente de trabalho, no qual os Zs buscam escritórios particulares ao invés de locais de trabalho conjuntos.

- Ligado a característica de integridade apresentada por Tapscott (2010), Jennings (2017) acredita que os Zs buscam companhias que apresentem propostas diretamente relacionadas a seus valores. "Quase $30 \%$ deles já são regularmente voluntários e $60 \%$ querem empregos onde possam tornar o mundo um lugar melhor. A empresa deve conseguir explicar de forma sucinta e convincente seu objetivo, seus valores e como vai impactar positivamente 0 mundo para despertar o interesse dessa geração". (JENNINGS, 2017).

- O espírito empreendedor está mais presente nos Zs do que estava nos millenials: "De acordo com a pesquisa da 360i, $72 \%$ deles querem abrir sua própria empresa". (JENNINGS, 2017).

- Multitarefas: Os Zs são multitarefas e conseguem prestar atenção às varias telas à sua frente, tanto quanto para alguém ao mesmo tempo.

- Curiosidade sem limites com relação a novos produtos e serviços. Com este ritmo acelerado, entretanto, pode parecer que a Geração Z não se aprofunda em nenhum assunto, já que o volume de informações que chegam instantaneamente é alto. Mas, pelo contrário, se este jovem se interessa por algum assunto, ele irá buscar mais informações sobre e se engajar a respeito. "Esta ampla gama de oportunidades e escolhas, torna-os muito seletivos de maneira rápida. Podemos dizer que esta é a forma de sobrevivência em um ambiente dinâmico onde vivem dependentes da tecnologia." (BLAKLEY, 2016 apud PUIU, 2016). 
- Descobridores: Ao contrário das gerações anteriores, os Zs quebram os padrões e acreditam que as descobertas devem ser feitas individualmente e no seu próprio ritmo, rompendo com a ideia de que tudo deve ser memorizado mecanicamente, como seus pais os educaram.

- Tecnologia como um direito: para este grupo, Internet é algo vital, assim como é o oxigênio e a água. Por terem nascido e crescido junto com a Internet, esta geração a vê como um direito que deve estar acessível a todos.

Com base nas características fundamentais desta geração, o estudo realizado pela Grail Research em 2011 (PUIU, 2016) identificou estratégias que as empresas devem realizar para fidelizar estes jovens. Foram identificadas as seguintes estratégias: anunciar seus produtos e serviços nas redes sociais, aplicativos e canais baseados na tecnologia; fidelizar os clientes desde o seu início de vida, aproveitando que os jovens são os primeiros a comprar e querem ter as novidades do mercado; estar sempre online, sendo um provedor de informação e facilitador no processo de compra; oferecer múltiplas soluções em um único produto, mesmo que custe mais caro; e oferecer produtos que respeitem o conceito de responsabilidade socioambiental, fator que pode influenciar a sua decisão de comprar, por trazer a tona o sentimento de contribuição para a sociedade.

Ao contrário do que parece, a presença online e em plataformas digitais também pode ser uma ameaça para as empresas, na medida em que os jovens têm mais acesso a informação e opiniões de outros clientes que já efetuaram compras com determinada empresa. Sendo assim, a concorrência fica mais acirrada e os clientes mais exigentes em encontrar o melhor produto/serviço que atenda as suas expectativas de preço e qualidade. Outro fator que gera maior complexidade para as empresas são as estratégias de marketing, que devem estar onipresentes nos variados canais de venda e relacionamento com o cliente (PUIU, 2016).

O elevado nível de exigência destes consumidores se manifesta de outras formas: falando sobre fidelização, um estudo da Ernst \& Young em 2015 (PUIU, 2016) aponta que os Zs veem frete grátis como um serviço já esperado, não sendo enxergado como valor agregado ao produto. Além disso, o estudo apontou que a experiência proporcionada pela marca tem mais valor do que o preço do produto. Outra descoberta importante é que, apesar de parecer ultrapassado, o marketing boca-a-boca tem muito valor para esta geração, pois diante de tantas opções de 
consumo, demonstra que o produto atingiu um patamar de qualidade que fez com que o cliente contasse a seus amigos, colegas e familiares. Sendo assim, as empresas devem cultivar um bom relacionamento com estes jovens no momento em que estes exercem alto poder de influência sobre suas vendas (PUIU, 2016).

Para cultivar este relacionamento de forma duradoura, um estudo do NIRSA de $2013^{4}$ (PUIU, 2016) evidencia a relevância de contratar profissionais focados em se comunicar com os jovens nas mídias sociais, como o Facebook e o Twitter. Esse estudo demonstrou que a conversão é maior quando a mensagem passada na campanha publicitária é objetiva e concisa. Essa constatação segue a forma que os jovens se comunicam nos canais virtuais: utilizando abreviações e sintetizando as mensagens longas para que elas sejam rapidamente lidas.

Seemiller e Grace (2013 apud PUIU, 2016) também acreditam que um fator importante que deve ser considerado nas campanhas de comunicação é o humor. Meir (2018) aponta os emojis e os gifs como importantes ferramentas de comunicação inclusive no ambiente de trabalho, aproximando as pessoas por meio das plataformas digitais. Van den Bergh e Behrer (2016 apud PUIU, 2016) reforça essa ideia, chamando a Geração Z de geração "emoji-onal", na medida em que estas animações são utilizadas para expressar seus sentimentos. Abaixo no gráfico, podemos observar algumas diferenças relacionadas à comunicação entre gerações que poderiam ser usadas pelas empresas:

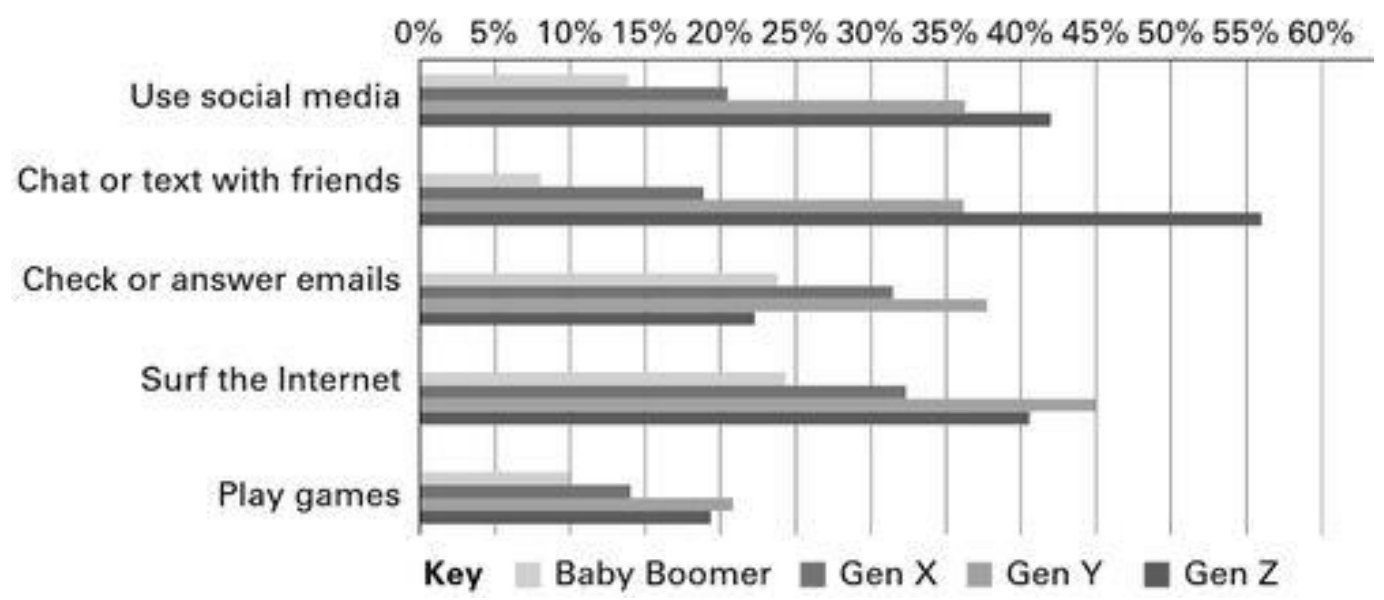

Figura 3 - Diferenças das preferências de comunicação entre as gerações. Fonte: Van den Bergh, J. (2015 apud PUIU, 2016).

\footnotetext{
${ }^{4}$ Generation Z: the Next Generation of College Students. 2013. Disponível em: https://www.jmu.edu/recreation/_files/presentations/gen-z-social- media.pdf
} 
O gráfico acima mostra que a geração $Z$, acima de qualquer outra, prefere conversar com amigos via mensagens de texto (56\%) e usar mídias sociais (cerca de $42 \%)$.

Essa nova geração de jovens requer uma nova geração de estratégias de comunicação em marketing para ser bem-sucedida. Um e-book da Havas People (2018) oferece seis dicas para empresas em relação às campanhas de comunicação voltadas para a Geração Z:

1. A empresa deve conseguir chamar a atenção destes jovens de forma rápida através de conteúdo curto. Isso porque estes jovens recebem muita informação simultaneamente, então quanto mais objetiva e certeira à mensagem, maior a conversão.

2. A utilização de imagens e vídeos nas campanhas é favorável para prender a atenção dos Zs, que respondem positivamente a este estimulo.

3. Criação de conteúdo compartilhável, lembrando que os jovens são influenciadores e tem uma audiência.

4. Incorporar a diversidade nas campanhas é muito importante, pois esta geração valoriza o multiculturalismo e a inclusão social, deixando de lado os preconceitos.

5. Garantir uma comunicação rápida com jovens nas mídias sociais.

6. Apesar de ser uma geração totalmente conectada, valoriza também o contato cara-a-cara. Portanto, as empresas devem preservar a comunicação humanizada.

Apesar de parecerem decididos e exercerem alto poder de influência, Sladek e Grabinger (2014 apud PUIU, 2016) pontuam a falta de identidade dos jovens, que veem as marcas como fatores externos que os apoiam para formação de sua individualidade. Nesse sentido, destacam a importância que as empresas representam quando criam identidades poderosas, capazes de moldar as identidades destes jovens em fase de consolidação de suas ideias, preferencias e interesses. Puiu (2016), por sua vez, não concorda totalmente com esta ideia porque "mostra que a Geração Z é confusa e carece de personalidade, quando, na verdade, todos os seres humanos tem uma personalidade única e todas as gerações parecem confusas quando são jovens. Mas marcas são importantes, muitos estudos provam que existe uma conexão importante entre 0 posicionamento das marcas e a auto percepção de seus clientes.". (PUIU, 2016). 


\subsection{Perfil socioeconômico dos jovens brasileiros}

Uma pesquisa realizada em 2012 com jovens da Geração Z na Índia pela Ericsson $^{5}$ (PUIU, 2016) confirmou que as diferenças não aparecem somente entre as gerações, mas também entre áreas geográficas, dependendo de fatores externos como o econômico, social e tecnológico. As variáveis que foram consideradas no estudo foram: telefones, conexão com a Internet, relação com os pais e as preferências dos jovens durante o tempo livre. Por isso, faz sentido entender as discrepâncias entre países e até mesmo regiões de um país para traçar os diferentes perfis socioeconômicos dos jovens.

A última pesquisa de Síntese de Indicadores Sociais (SIS) realizada no Brasil em 2015 aponta que os jovens de 15 a 29 anos representam cerca de um quarto da população, o que equivale a 48,3 milhões de brasileiros. Este grupo etário está, em sua maioria, concentrado na região Norte do país (BRETAS, 2016). A ilustração abaixo mostra a distribuição dos jovens entre as cinco regiões brasileiras:

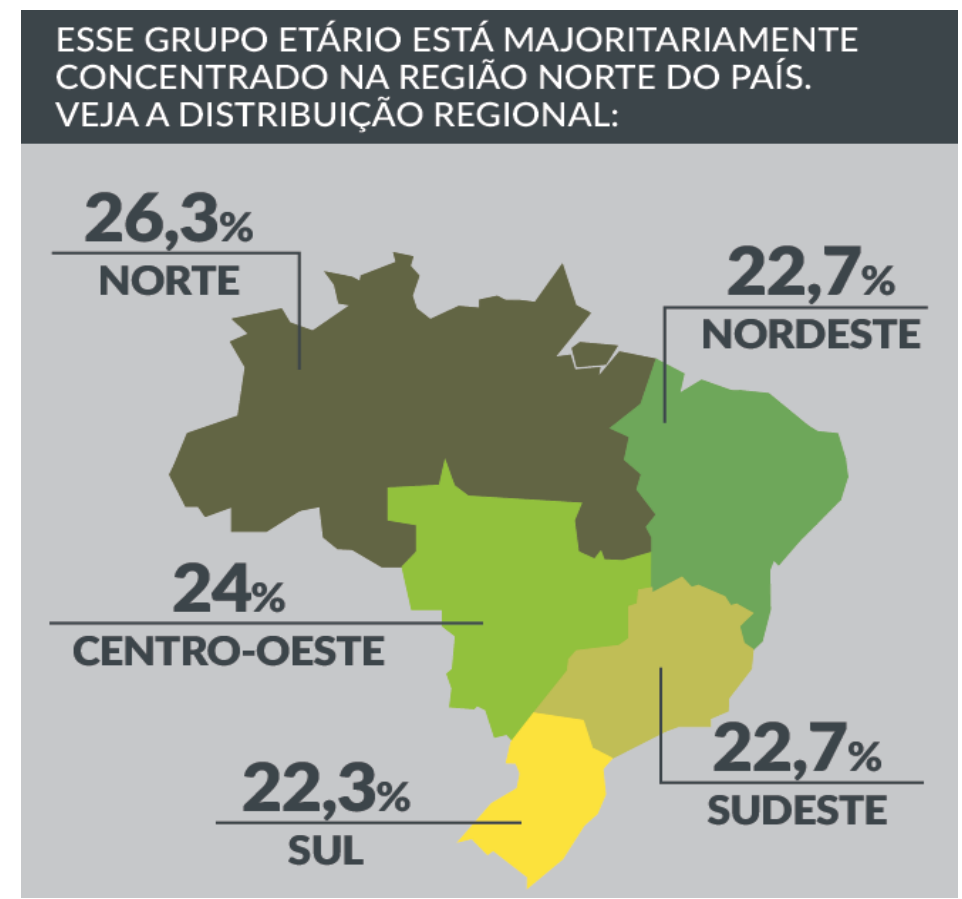

Figura 4 - Distribuição dos jovens entre as cinco regiões brasileiras. Fonte: IBGE/SIS (2015 apud BRETAS, 2016).

5 Generation Z - Understanding the digital lives of India's young mobile users. Disponível em: https://www.ericsson.com/assets/local/news/2012/11/consumerlab-generation-z.pdf 
Segundo a mesma pesquisa, 44\% desse grupo etário trabalhava, 20,8\% só estudava e 15,4\% trabalhava e estudava simultaneamente. Outra constatação foi que $60 \%$ destes jovens já estavam casados e com filhos. Em contrapartida, $13,3 \%$ ainda moravam com os pais e apenas $2,3 \%$ viviam sozinhos. A renda média mensal deste grupo não ultrapassou dois salários mínimos, valor que não chega a $R \$ 1.800,00$ mensais. Apesar disso, a remuneração era inferior dez anos antes: em 2005, 32,6\% ganhavam até dois salários mínimos e 11,7\% viviam com meio salário mínimo. Em 2015, as pessoas passaram a ganhar mais: 43,8\% recebiam até dois salários mínimos e 8,2\% ganhavam até meio salário. (BRETAS, 2016).

Vale ressaltar que o Brasil é um dos países mais desiguais da América Latina e $010^{\circ}$ pais mais desigual do mundo, diagnóstico revelado pelo Programa das Nações Unidas para o Desenvolvimento (PNUD) através do Índice de Desenvolvimento Humano (IDH) e Índice de Gini. (MATOSO, 2017; CORRÊA, 2017).

Essa desigualdade se reflete também entre as cinco regiões do país. Em 2017, o índice de Gini, principal medida de desigualdade de renda, apontou que apesar da queda de desigualdade de renda na região Sudeste, ela cresceu no restante do país, especialmente no Nordeste, com um aumento de 0,05 ponto no índice, especialmente por conta da perda de emprego da população em conjunto com a redução de residências que recebem o benefício da Bolsa Família (CIMAR, 2018 apud VILLAS BOAS, 2018). Isso demonstra a acentuada disparidade entre as regiões brasileiras, refletindo também no comportamento de compra dos jovens no país. (VILLAS BOAS, 2018).

Uma pesquisa realizada pela Pontifícia Universidade Católica do Rio Grande do Sul (PUC-RS) com 1.500 brasileiros de 18 a 34 anos, aponta que os jovens sentiram a crise. Além de começarem a trabalhar mais cedo por questões de necessidade, os jovens estão cada vez menos saindo da rotina, deixando de lado atividades fora do lar como esportes, festas, shoppings e restaurantes. A pesquisa aponta também que o cansaço e falta de segurança sentidos pelos jovens também acabam desestimulando-os a realizar atividades fora de casa. (Blog PUC-RS, 2018).

\subsection{O Comportamento de consumo da Geração Z}

Levy e Weitz (2000) apontam que indivíduos pertencentes à mesma geração demonstram comportamento similar de compra, por compartilharem as mesmas experiências e estarem no mesmo estágio de vida. Por isso, como 
indivíduos de distintas gerações apresentam características também distintas em relação a suas atitudes e comportamento de compra, as empresas fazem campanhas específicas direcionadas para cada um dos grupos geracionais, com o objetivo de alcançá-los de forma mais assertiva. (BERKOWITZ et al, 2003 apud CERETTA e FROEMMING, 2011).

Atualmente, a Geração Z carrega bilhões em poder de consumo, de acordo com o New York Times Journal, demonstrando o peso que este grupo já exerce na economia. Por anos, as empresas estudaram as gerações anteriores aos Zs e depois de muito testarem, conseguiram ser bem sucedidos nas suas decisões estratégicas. Porém, o foco agora deve ser a Geração Z, que já está superando os Millenials em número de pessoas. (TRENDS EMAGAZINE, 2017).

A consultoria WGSN realizou uma pesquisa em 2015 com jovens da geração $Z$ para entender o que esperam dos varejistas. Os resultados foram em linha com as características dessa geração. O que eles esperam são marcas que tragam experiências e praticidade, personalização, diversidade e múltiplas telas convergentes (NOVAES, 2015). Na pesquisa realizada em 2016 pela mesma consultoria, foi levantado que os Zs também querem mais diversão, momentos reais que possam ser compartilhados nas redes sociais (Instagram, principalmente) e wifi de qualidade. O valor está mais nas experiências e menos nas compras. Neste sentido, as alamedas gourmet e praças de alimentação se destacam, já que segundo a consultoria financeira Piper Jaffray em 2016 (FOCUS, 2017), bebidas e alimentos representam $24 \%$ dos gastos dos adolescentes, enquanto as roupas ficam com apenas 19\% (FOCUS, 2017).

Uma pesquisa realizada pela IBOPE mídia (2010) confirma estas expectativas através do que os jovens brasileiros da Geração Z consideram como diversão. Para este grupo, composto em sua maioria por estudante (84\%), diversão se traduz em jogar games (mais de $50 \%$ possui videogames), praticar esporte (consomem muitos equipamentos e artigos esportivos) e ouvir música (38\% tem um MP3, ficando 10pp acima da média populacional). (SAWAIA, 2010).

Este comportamento difere dos membros da geração $Y$, que se mostram mais consumistas do que a geração $Z$. Por isso, a geração $Y$ sai na frente quando o assunto é gastar em produtos sem pensar, enquanto os Zs tem mais afinidade com as marcas que sejam divertidas e inovadoras no momento da compra (SAWAIA, 2010).

A fim de chamar este público, foram levantadas algumas ações pela consultoria WGSN que devem ser realizadas pelos varejistas: "os varejistas 
precisam oferecer uma experiência superior à do ambiente virtual e enriquecer a vida social dos consumidores, de uma forma que as redes sociais não conseguem". Assim, é necessário investir em entretenimento e produtos em linha com os gostos dos adolescentes (FOCUS, 2017).

Outras tendências foram identificadas através de um estudo realizado pela Officina Sophia Retail em agosto de 2016 com 1.200 jovens brasileiros e latinoamericanos entre 13 e 18 anos das classes A, B e C. Valéria Rodrigues, diretora da Officina Sophia Retail e responsável pela pesquisa afirma que "existe espaço para que a loja física se torne um centro de experiência com o produto e com marcas, permitindo, até mesmo, compras no ambiente digital e com oferta de serviços agregados". (O NEGÓCIO DO VAREJO, 2016). A pesquisa também apurou que: $43 \%$ destes gostariam que os pontos de venda fossem separados por categoria de produtos; $42 \%$ querem lojas que possam customizar suas roupas; $39 \%$ gostariam de provar roupas através de provadores digitais; e 27\% desejam livrarias que respeitem a sustentabilidade (MENDONÇA, 2017).

Com relação aos espaços físicos, as preferências são por espaços que trazem sensação de bem-estar e prazer (60\%), espaços acolhedores (34\%) e apenas $28 \%$ prezam por um tratamento VIP, defendendo que os espaços devem ser "exclusivos, únicos e especiais". (MENDONÇA, 2017).

Em suma, o que estes novos consumidores mais exigentes esperam dos shoppings são mais áreas de socialização, convivência, ambientes verdes, iluminação natural, wifi gratuito e de qualidade, games interativos, mini shows, experiências com realidade aumentada e virtual, pista para andar de skate, e espaços para levar os seus pets (WERNECK, 2017).

\subsection{Experiência do Consumidor nos Shopping Centers}

Diversos estudos apontam que a motivação de consumo pode ter componentes de natureza subjetiva, sendo então caracterizado pela dimensão hedônica, ou de natureza funcional, a dimensão utilitária, segundo HOR-MEYLL e FIGUEIRA (2013). A dimensão utilitária é associada à praticidade e busca a resolução de forma racional de algum problema. Ou seja, essa dimensão é satisfeita quando um produto ou serviço apresenta benefícios funcionais que advém do seu uso ou consumo. Já a dimensão hedônica, é associada com a emoção e prazer, pois ao contrário de se manifestar nos atributos funcionais do produto ou serviço, se manifesta de forma intrínseca através da experiência proporcionada. Os autores citam trabalhos relevantes na área como os de 
HIRSCHMAN e HOLBROOCK (1982), BATRA e ATHOLA (1990), e BABIN et al. (1994) que ajudaram a revelar essa dimensão.

Apesar de serem conceitos distintos, ambas as motivações se complementam, pois é comprovado que se o produto vem acompanhado de uma experiência durante o processo de compra, esta se torna mais agradável (HORMEYLL e FIGUEIRA, 2013). Isso porque, a experiência pode trazer o prazer associado a quatro dimensões de acordo com Dubé et al (2003 apud ALBUQUERQUE et al., 2010): sensorial ou físico, que seriam as sensações que a experiência proporciona; o emocional, que seriam os sentimentos e pensamentos; o social, ligado as relações com outras pessoas; e o intelectual, que seriam os ensinamentos da experiência.

A diversão e o entretenimento oferecidos no ponto de venda desempenham o papel de aumentar a satisfação do consumidor, na medida em que tornam sua experiência de compra agradável e memorável, contribuindo para o valor agregado dos bens e serviços da marca, como mostram diversas pesquisas levantadas por Pantano e Naccarato (2010).

O entretenimento é também utilizado como forma de agregar valor a experiência dos clientes e muitos estudiosos avaliam quais aspectos contribuem para esta experiência no ponto de venda e a comunicação da marca com seu público. (Pantano e Naccarato, 2010). Já existem cases de lojas que incluíram espaços de experiência com este intuito. No Brasil, por exemplo, a Rua Oscar Freire, em São Paulo, é conhecida por atrair lojas-conceito de marcas renomadas, com o objetivo de proporcionar experiências aos seus clientes. Algumas destas lojas são a Schutz, Cavalera, a Nike Store, entre outras (FRANÇA, 2009).

Portanto, mais do que um espaço de compras, estes locais proporcionam entretenimento, que com a ajuda da tecnologia, garantem a melhor experiência nas lojas virtuais e físicas. Alguns dos desejos da geração Z já podem ser realizados por estas marcas com o avanço tecnológico. Um exemplo disso são os espelhos inteligentes, demonstrando como é possível os clientes interagirem com os produtos a venda de forma rápida e prática. Sendo assim, "a principal característica que a tecnologia traz ao varejo é a interatividade" (Pantano e Naccarato, 2010). Autores como Kim et al. (2007) e Yoo et al. (2010) (apud Pantano e Naccarato, 2010) mostram como essas tecnologias interativas tem sido usadas pelos varejistas para propiciarem experiências de compra diferenciadas.

Fica evidente, então, que a conversão aumenta quando ambas as dimensões são incorporadas ao processo de compra (Kim e Kim, 2008 apud 
Pantano e Naccarato, 2010). Hor-Meyll e Figueira (2013), por exemplo, levantaram exemplos de aspectos que influenciam na motivação hedônica e que foram explorados em diversas pesquisas: embalagem do produto, design diferenciado, tecnologia no ponto de venda, entre outras.

Trazendo para a realidade de shopping center, Lima (2008 apud HORMEYLL e FIGUEIRA, 2013), faz alusão as motivações utilitárias como "fazer refeições" e "pesquisar preços", enquanto a socialização seria uma motivação hedônica. Neste exemplo, a motivação hedônica aparece também como motivação social.

Além das dimensões hedônica e utilitária, existe também a dimensão social, acrescentada por alguns autores que acreditam que o encontro de pessoas no ambiente do shopping afetam a sua atratividade bem como o comportamento do consumidor. Segundo uma pesquisa realizada pelo Instituto Officina Sophia em 2016 (MUNDO DO MARKETING, 2017) com brasileiros de 14 a 18 anos, apenas $16 \%$ dos jovens vão ao shopping para fazer compras. Enquanto isso, $80 \%$ destes jovens afirmam ir ao shopping para vivenciar momentos de lazer e socializar, dentre eles: assistir um filme no cinema, passear com a família e amigos e comer. Sendo assim, o shopping é enxergado como life center pelos jovens brasileiros. Se compararmos com outros países da América Latina, 31\% dos jovens vão ao shopping para fazer compras, demonstrando a diferença nos hábitos de lazer e consumo dos brasileiros (MENDONÇA, 2017). 


\section{Metodologia de Pesquisa}

\subsection{Tipo de pesquisa}

O presente estudo trata-se de uma pesquisa de caráter exploratório, considerando que o tema é emergente em Administração. O tipo de pesquisa realizado é qualitativo, composto de entrevistas em profundidade. Para Kotler e Keller (2013), a técnica qualitativa representa um método de mensuração relativamente não estruturado, permitindo uma vasta gama de respostas possíveis. Sendo assim, se mostra mais efetivo para avaliar a opinião dos consumidores no momento em que suas ações nem sempre correspondem às suas respostas dadas em métodos quantitativos. Zikmund (p.50, 2006) constatou que a pesquisa exploratória funciona para esclarecer e definir a natureza de um problema. Suas respostas não são conclusivas, porém, é possível direcionar pesquisas posteriores que podem ser realizadas a fim de detalhar resultados quantitativos com maior precisão.

Além disso, para Kotler e Keller (2013), os contatos pessoais são um método mais versátil, já que o entrevistador pode fazer mais perguntas e registrar observações sobre o entrevistado que demonstrem o seu comportamento e características individuais.

\subsection{Seleção de sujeitos}

O universo da pesquisa de campo é representada pelos jovens consumidores do Rio de Janeiro, pertencentes ao que se define como Geração Z. Além desta definição, um dos critérios para seleção dos respondentes foi o de frequentar mensalmente um ou mais shoppings, no mínimo, e ser morador do estado do Rio de Janeiro. Dentro deste filtro, não houve restrição quanto ao gênero, grau de escolaridade ou renda dos respondentes. Inclusive, houve preferência por buscar um público diferenciado dentro da faixa etária selecionada a fim de retratar a realidade desigual do país. 
A amostra analisada contou com 15 participantes cuja abordagem foi realizada presencialmente em shoppings centers na Zona Norte do Rio de Janeiro: Shopping Tijuca e NorteShopping e na Universidade PUC-RIO na Gávea, Zona Sul do Rio de Janeiro. Estes jovens tinham de 16 a 22 anos e apenas um entrevistado já havia completado Bacharelado. As distintas áreas de formação e locais de residência no Rio de Janeiro trouxeram perspectivas diferentes, enriquecendo os debates e trazendo ideias variadas. O tempo aproximado de cada entrevista era, em média, de 20 minutos.

Todos os entrevistados foram recrutados de forma voluntária e conscientes de que estavam contribuindo para um trabalho acadêmico. Na Tabela 1, é apresentado o perfil dos participantes da pesquisa com gênero, idade, estado e zona de moradia, área de especialização e grau de formação.

Tabela 1 - Perfil dos entrevistados. Fonte: Elaborado pela autora, 2018.

\begin{tabular}{|c|c|c|c|c|c|c|}
\hline Identificação & Gênero & Idade & Estado & Zona & Área & Grau \\
\hline E1 & Feminino & 21 & RJ & Norte & Relações Internacionais & Bacharelado Incompleto \\
\hline E2 & Feminino & 19 & RJ & Norte & Psicologia & Bacharelado Incompleto \\
\hline E3 & Masculino & 22 & $\mathrm{RJ}$ & Norte & Engenharia & Bacharelado Incompleto \\
\hline E4 & Feminino & 18 & RJ & Norte & Escola & Ensino médio incompleto \\
\hline E5 & Masculino & 20 & $\mathrm{RJ}$ & Norte & Administração & Bacharelado Incompleto \\
\hline E6 & Masculino & 22 & $\mathrm{RJ}$ & Norte & Sociologia & Bacharelado Incompleto \\
\hline E7 & Masculino & 17 & $\mathrm{RJ}$ & Oeste & $\mathrm{TI}$ & Bacharelado Incompleto \\
\hline E8 & Feminino & 16 & RJ & Norte & Escola & Ensino médio incompleto \\
\hline E9 & Masculino & 17 & $\mathrm{RJ}$ & Norte & Escola & Ensino médio incompleto \\
\hline E10 & Feminino & 22 & $\mathrm{RJ}$ & Sul & Design & Bacharelado Incompleto \\
\hline E11 & Masculino & 18 & $\mathrm{RJ}$ & Norte & Escola & Ensino médio incompleto \\
\hline E12 & Feminino & 16 & RJ & Norte & Escola & Ensino médio incompleto \\
\hline E13 & Feminino & 22 & $\mathrm{RJ}$ & Sul & Administração & Bacharelado completo \\
\hline E14 & Feminino & 22 & $\mathrm{RJ}$ & Sul & Engenharia & Bacharelado Incompleto \\
\hline E15 & Feminino & 22 & $\mathrm{RJ}$ & Sul & Direito & Bacharelado Incompleto \\
\hline
\end{tabular}

\subsection{Análise dos dados}

Os dados foram coletados por meio de entrevistas gravadas em áudio com prévia autorização dos participantes. Após a conclusão desta etapa inicial, as gravações foram analisadas utilizando o método da classificação de termos e ideias. Motta (1999) afirma que este tipo de mensuração busca identificar termos e padrões de ideias extraídos de textos longos e classificar as respostas em classes de análise de forma clara e precisa. Para minimizar as dificuldades de tirar conclusões com as respostas, é preciso seguir dois tipos de orientações fundamentais: objetividade e sistematização. (MOTTA, 1999).

A objetividade garante que a análise se restrinja apenas ao estudo da mensagem. Já a sistematização estabelece a inclusão ou não de determinado conteúdo em uma classe determinada (MOTTA, 1999). A determinação dessas 
classes pode ser realizada por dedução ou indução. Para o presente trabalho, utilizou-se o método de redução de dados por indução, na medida em que as classes foram definidas de acordo com o conteúdo encontrado nas respostas dos entrevistados.

\subsection{Limitações do Estudo}

Tendo sido realizada uma pesquisa qualitativa com uma amostra relativamente pequena e selecionada usando um procedimento de amostragem não-probabilístico por conveniência, não foi possível identificar padrões de comportamento e desejos presentes em todos os respondentes do universo de interesse da pesquisa. Portanto, as conclusões das entrevistas não podem ser generalizadas para populações mais amplas e diversificadas (KOTLER; KELLER, 2013). 


\section{Apresentação e análise de resultados}

Este capítulo tem como objetivo apresentar os dados coletados e analisar os resultados obtidos dividindo-os em classificações com base nos termos e ideias apresentados nas entrevistas. A análise das transcrições das entrevistas resultou na criação de sete categorias de análise, que serão descritas a seguir. Estas categorias são: lazer em geral, lazer em shopping, conveniência em shopping, experiência nos shoppings frequentados, características essenciais ao shopping, shopping como lugar de encontrar e estar com pessoas e shopping ideal.

\subsection{Lazer em geral}

Quando questionados sobre as atividades de lazer que mais gostavam de fazer nas horas vagas, os entrevistados mencionaram: ver filmes e séries, ler livros, navegar na internet, tocar violão, tirar fotos e jogar games. Estes hobbies estão em linha com as características da geração $Z$, principalmente o último, em sinergia com a pesquisa IBOPE sobre o que este grupo entende como diversão: 84\% mencionam jogar games (SAWAIA, 2010). Além disso, apareceram outros hábitos de lazer como: andar de skate, dançar, passear com o cachorro, sair para bares, ir à praia e fazer trilhas. Assim, podemos ver que, apesar de terem crescido junto à tecnologia, estes jovens valorizam os momentos de lazer ao ar livre, buscando experiências em locais abertos e amplos.

Quanto às opções de lazer fora de casa no Rio de Janeiro, uma parte dos entrevistados acredita que existem muitas opções de lazer relacionadas à natureza, como praias, trilhas e parques. Porém, a insegurança foi levantada como fator crítico, em linha com o resultado da pesquisa feita pela PUC-RS, que apontou a falta de segurança sentida pelos jovens como fator que os desencoraja a realizar atividades fora de casa (Blog PUC-RS, 2018).

Foi possível observar o shopping como uma opção de lazer secundária por conta da carência destes espaços diferenciados. Ou seja, isso significa que, se existisse uma maior variedade de opções de lazer indoor com segurança, o shopping poderia não ser considerado como um espaço de lazer por estes jovens, que sentem falta de locais diferenciados que ofereçam programas culturais e de entretenimento, como exposições artísticas, teatros, palestras e shows. 
"Acho que até teria (mais opções de lazer) se a cidade fosse mais segura, porque tem muito lugar de natureza bonito. Mas por ser inseguro, eu acabo vindo muito aqui no Shopping, que é perto de casa." (E2)

"(Gostaria de ver) exposições artísticas, que podem ser de quadros, de moda, desfiles, etc. Tem muitos shoppings do Sul e de São Paulo que oferecem estas experiências, aqui no Rio carece muito deste tipo de experiência." (E10)

O shopping foi levantado também como uma alternativa de lazer em dias com mau tempo, pois não há como usufruir de espaços abertos da cidade como praias, parques e estabelecimentos abertos. Novamente, aparece como uma opção secundária e não como destinação preferida dos jovens, evidenciando que há espaço para melhorias por parte das administradoras de shoppings em termos de estratégias de marketing.

"Acho que quando o dia está bonito tem muitas coisas legais pra fazer, como ir ao parque, a praia, um bar ao ar livre ou mesmo caminhar no calçadão. Mas sinto que quando o dia está feio, não tem quase nada pra fazer, só ir ao shopping, que muitas vezes não tem filmes bons no cinema." (E15)

Outros entrevistados mencionaram que existem sim opções suficientes de lazer que os satisfaçam no Rio de Janeiro. Estes consideram lazer como ir à praia, ver filmes no cinema, ir ao shopping e a restaurantes. Além disso, dizem que existem todas estas opções no Rio de Janeiro.

"Sim, (acho que existem opções suficientes de lazer fora de casa) aqui na Tijuca tem o shopping. Eu vou à praia também no final de semana." (E8)

\subsection{Lazer em shopping}

Durante as entrevistas, foi possível identificar que a percepção com relação ao shopping muda dependendo na Zona em que o jovem mora. Dos dez moradores da Zona Norte entrevistados, nove veem o shopping como forma de lazer e conveniência, despertando as motivações hedônica, utilitária e social ao longo de sua experiência.

Estes entrevistados que veem o shopping como forma de lazer defendem que ele se manifesta dentro da categoria através de todas as opções de restaurantes, cinema, teatro, além da socialização, tudo em um único local. 
Mencionaram que um bom shopping deve ter um cinema e um bom teatro, com uma oferta boa de filmes e peças. O momento de visita pode ser aos finais de semana como forma de entretenimento e lazer e durante a semana com menor frequência para solucionar alguma questão mais rotineira, como é o caso de jovens que estudam neste empreendimento. Isso demonstra que o shopping pode ter perspectivas diferentes na visão da mesma pessoa, porque existem diversas ocasiões em que ele pode ser visitado.

"Eu acho o shopping um lugar confortável, mais por ser um lugar versátil, tem todos os tipos de restaurantes, eu posso descer comer a comida que eu quiser, eu posso ir ao cinema, posso ir ao teatro com meus amigos..." (E2)

"Sim, porque mesmo estudando aqui no shopping eu também venho no final de semana pra comer e ver filmes. Adoro passear também com meus colegas de turma. Gosto muito de tirar fotos no shopping também e publicar no meu perfil."

\subsection{Conveniência em shopping}

Foi apresentada também uma postura mais utilitária ou funcional no que se refere à experiência de ir ao shopping. Isso porque alguns veem o shopping como um local de conveniência e "resolução de problemas", já que podem encontrar muitas lojas, restaurantes e serviços em um único local. Esta característica já havia sido mencionada por Wood (2013 apud PUIU, 2016), que afirma que por ser uma geração que cresceu num ritmo muito acelerado em termos de evolução tecnológica, querem resolver tudo de forma prática e rápida, valorizando a conveniência e velocidade, alinhado ao propósito inicial da criação do shopping (SEMMA GROUP, 2012).

Porém, além de uma experiência funcional, a exemplo de fazer compras, estes afirmam que a resolução de um problema deve vir ligada a uma experiência prazerosa e de baixo atrito, reforçando a ideia de que ambas as dimensões utilitária e hedônica se complementam. Estes que apontam o shopping como espaço de conveniência, costumam frequentar durante a semana o shopping que seja próximo de casa ou de onde estudam/trabalham, por comodidade.

"Eu costumo ir (ao shopping) mais para acompanhar os lançamentos das lojas porque faço design de moda e gosto de acompanhar as novidades."(E10) 
"Eu venho mais pela praticidade de ter tudo em um lugar só. Foi bom vir ao shopping pois eu consegui encontrar um lugar tranquilo para estudar e tomar um café, com wifi gratuito e segurança”. (E13)

Assim como observado no tópico "Lazer em Geral", a preferência pelo lazer ao ar livre foi destacada, evidenciando que não necessariamente a experiência deva vir acompanhada de inovações tecnológicas para ser prazerosa. Por ser uma geração que enxerga a tecnologia como algo vital e já totalmente incorporado a sua rotina (Jennings, 2017), evidencia-se a busca pelo escapismo, ou seja, o desejo de escapar do dia-a-dia através de experiências ao ar livre, conforme Wood (2013 apud PUIU, 2016) já havia levantado.

"Só vou ao shopping quando tenho que comprar alguma coisa, ou pra comer também, mas não como forma de lazer. Prefiro lugares ao ar livre." (E6)

"Acho que o shopping traz esse conforto e segurança e sempre ótimas opções de compra pelo mix de lojas. Mas, não vejo como uma opção de lazer até porque prefiro passear em espaços abertos.". (E15)

\subsection{Experiência nos shoppings frequentados}

Quando perguntados sobre o shopping favorito, os moradores da Zona Norte e Zona Sul levantaram diferentes opções. Os moradores da Zona Norte levantaram: Shopping Tijuca e NorteShopping, enquanto os moradores da Zona Sul preferem os Shoppings Leblon e da Gávea.

O NorteShopping foi levantado como um shopping com boa localização na Zona Norte, bom mix de lojas e serviços, boas promoções e preços, eventos com inovação, boa infraestrutura de estacionamento e bom ambiente físico.

Novamente, o espaço aberto do pátio apareceu como ponto forte do ambiente físico do shopping, no qual foi sugerido a inclusão de uma pista de skate e bicicleta. Falando sobre mix de lojas e serviços, os elogios foram com relação à variedade de lojas, que abrangem todas as classes sociais. Sobre eventos com inovação, foram mencionados o evento de Karaokê e eventos com personagens infantis, em parceria com a Disney. 
"NorteShopping (é o meu preferido) porque é mais próximo, mix de lojas me atende, cinema é melhor, tem preços mais acessíveis e sou acostumada. É um local de conveniência, eu consigo resolver várias rotinas em um único lugar."

"Gosto de ambientes que misturem espaço aberto com espaço fechado, tipo aqui no Norte que tem o pátio. O bom é que lá acontecem também vários eventos. Ano passado teve um planetário daquele desenho da Luna, todo temático do Natal. Trouxe minha sobrinha e ela gostou muito, é muito bom para as crianças se divertirem também." (E2)

"NorteShopping (é o meu preferido) porque o cinema é melhor, tem o teatro e tem eventos inéditos, como o Karaokê que está tendo no pátio. Gosto muito do espaço aberto que tem lá também, pois consigo passear ali e ver como está o dia." (E2)

Em termos de críticas, o NorteShopping foi citado por ser um shopping muito cheio, com grupos de jovens que fazem bagunça e poucos restaurantes que proporcionem experiências gourmet diferenciadas. A bagunça e o alto fluxo podem causar uma experiência desagradável no shopping, por gerarem tumulto e filas no shopping, violando a proposta de baixo atrito para o cliente.

"Às vezes tem grupos no shopping que fazem muita bagunça e deixam os outros clientes desconfortáveis. Isso principalmente no Norte Shopping, que tem uma escola dentro e os alunos costumam fazer o "recreio" deles no shopping. Se no NS tivesse opções melhores de restaurantes, um espaço gourmet, seria melhor. O espaço aberto da expansão tem poucas opções diferenciadas de restaurante. A varanda tem quatro opções apenas de restaurantes."

O Shopping Tijuca foi citado pela sua localização, pelos bons restaurantes na alameda gourmet, bom mix de lojas, ambiente agradável, incluindo decoração interna, iluminação, música ambiente, temperatura e segurança. Um pilar muito forte do shopping mencionado pelos entrevistados foi o de gastronomia através do ambiente exclusivo proporcionado pela Alameda Gourmet, em linha com o que 
foi levantado na pesquisa feita pela WGSN em 2016 (FOCUS, 2017), afirmando que as experiências de alimentação se destacam entre os jovens da Geração Z.

Sobre o mix de lojas, foi mencionado o fato de o shopping possuir as grandes âncoras de vestuário, como a Renner e Forever 21. O ambiente agradável se deu no momento em que a temperatura foi elogiada, bem como o atendimento dos seguranças dentro do shopping.

"Gosto muito dos restaurantes. Eles fizeram uma alameda gourmet agora que tem uns bons restaurantes como o Galli, o Gula Gula, o Entrecote. E tem também o Outback lá no subsolo que eu sempre comemoro meu aniversário."

"Tijuca tem muitos bons restaurantes. Gosto do ambiente também que tem um bom ar condicionado, lojas boas e os seguranças são prestativos

também." (E5)

"(Vir ao shopping Tijuca) é o meu programa favorito do final de semana, porque é um momento que eu tenho pra passear sem me preocupar. Eu adoro ver as lojas Renner e abriu também a Forever 21 que tem novidades toda a semana." (E8)

Quanto às críticas feitas pelos entrevistados, destacam-se a infraestrutura do estacionamento, a praça de eventos do shopping, que além de ficar no subsolo, tem pouco espaço para os eventos. Foi levantada também a carência de uma área aberta, de espaços de convivência e de wifi de qualidade, conforme ilustrado nos depoimentos abaixo.

"Poderia ter mais áreas abertas no Tijuca, como tem no NorteShopping. O SAC também é muito escondido lá... A praça de eventos do shopping é bem pequena também, então não tem muito espaço para fazer eventos diferenciados como no Norte." (E1)

"No caso do Tijuca, sinto falta de um espaço aberto, uma varanda por exemplo. Sinto o shopping muito fechado. Não tem nem janelas. Sinto falta também de um wifi de qualidade e espaços de convivência." (E5) 
O Shopping Leblon, que é um shopping mais premium, foi levantado como um shopping com boa localização, bom público que o frequenta, ambiente agradável, ótima estrutura, segurança e um ambiente de boa interação social. O que se entende como um ambiente agradável é pelo conforto e modernidade da estrutura, além do espaço amplo e pouco poluído por quiosques.

"São pessoas de classe alta, que se vestem bem e tem bom gosto. Acho que é bem frequentado." (E10)

"Gosto do ambiente, acho bem confortável e moderno. Além disso, gosto que o wifi funciona bem e das lojas. Tem muitas lojas de grife." (E10)

As críticas que os entrevistados fizeram ao shopping Leblon dizem respeito à carência de espaços abertos, verdes e atividades/serviços diferenciados, como exposições, palestras e um espaço de coworking. Outra crítica ao shopping diz respeito ao atendimento pouco qualificado dentro das lojas, no que diz respeito a vendedores pouco prestativos e que apenas "empurram" produtos para garantir suas vendas, pois isso pode comprometer o relacionamento de longo prazo com as marcas. Essa crítica está em linha com o perfil mais exigente desta geração, que não compra por comprar, mas sim pelo envolvimento e experiência proporcionados no ponto de venda (SAWAIA, 2010), demonstrando o valor que a fidelização se dá nos dias atuais.

"Falta uma área verde, aberta, com atividades culturais, como exposições e um palco, para receber shows e palestras." (E10)

"Sinto falta de um atendimento de qualidade dentro das lojas. Quando falo qualidade, não significa ter alguém em cima de mim para me induzir a fazer uma compra. Mas um atendimento mais qualificado, mais prestativo e com o intuito de ajudar mesmo o cliente de forma natural e sincera e não só converter em venda." (E13)

“Já fui má atendida algumas vezes em lojas, principalmente quando fui para trocar um presente e o atendimento foi péssimo, o que fez com que eu nunca mais comprasse na loja do Shopping Leblon." (E13) 
Por fim, o Shopping da Gávea foi pontuado por um dos entrevistados como um shopping com boa localização, ótimo ambiente de lazer através das peças e filmes culturais em cartaz, variedade de restaurantes para todos os gostos, ambiente agradável e elevada interação social, por estar localizado próximo a faculdade PUC, tendo muitos visitantes jovens e que convivem no mesmo ciclo social.

"Almoço muito no shopping da Gávea, e eventualmente eu compro alguma coisa quando preciso. Já fui algumas vezes ao teatro e cinema também."

"A frequência da Gávea é ótima, tem muitos conhecidos que estudam na PUC e frequentam o shopping, então sempre acabo encontrando alguém lá."

\subsection{Características essenciais aos shoppings}

Os tópicos conforto, conveniência e segurança oferecidos pelo ambiente de Shopping foram mencionados por todos os entrevistados. O lazer também foi mencionado como básico por ser um espaço acessível que ofereça cinema, restaurantes e ser um local para estar presente com amigos e família. Porém, a expectativa destes jovens é de que o shopping ofereça mais do que este checklist que é considerado básico e inerente a estes empreendimentos nos dias de hoje. Por exemplo, um item que é considerado essencial atualmente pela geração $Z$ é o wifi, conforme já havia sido levantado pela pesquisa da WGSN em 2016 (FOCUS, 2017).

"Vejo wifi como algo que não pode faltar de jeito nenhum no shopping. Até porque muitas vezes tenho que encontrar meus amigos ou familiares ou até mesmo pedir um uber, mas tenho dificuldade de me conectar na internet de shoppings. Na maioria das vezes tenho que usar minha internet ou fico sem conexão." (E7)

"Algumas vezes eu já fui especificamente para usar o Starbucks, por conta do wifi e do ambiente de cafeteria que você pode estudar, usar um notebook, fazer um trabalho, resolver algumas coisas ali de forma rápida. Isso é bem importante." (E10) 
Os depoimentos acima evidenciam a relação de dependência que os jovens desenvolveram com relação à internet, revelando a necessidade de estarem sempre conectados nas mídias sociais e aplicativos que ofereçam serviços práticos e convenientes no dia-a-dia. Isso reforça a estratégia já identificada pela pesquisa Grail Research em 2011 (PUIU, 2016), de que as empresas devem anunciar seus produtos e serviços nas redes sociais, aplicativos e canais baseados na tecnologia, além de estarem sempre online, provendo informações e facilitando o processo de compra. A estratégia mencionada funciona tanto para as marcas presentes nos shoppings como para os próprios empreendimentos, que apesar de estarem inseridos no varejo físico, devem também oferecer plataformas digitais, como wifi e aplicativo, evitando filas e alto tempo de espera. Desta forma, é possível quebrar as barreiras que ainda existem entre os canais online e off-line, apresentando estratégias de marketing que estejam onipresentes nos variados canais de venda e relacionamento com 0 cliente (PUIU, 2016).

\subsection{Shopping como lugar de encontrar e estar com pessoas}

Os resultados da pesquisa sugerem o que já havia sido levantado pelo ebook da Havas People (2018): apesar de ser uma geração totalmente conectada com o mundo virtual, valoriza também o contato cara-a-cara. Esta interação entre amigos, familiares e colegas de trabalho tem espaço também nos shoppings centers no Rio de Janeiro, enxergados como locais para encontrar e estar com pessoas, especialmente familiares.

Esta descoberta pode trazer inspiração e ideias para as administradoras pensarem em eventos, ações e serviços que possam satisfazer e integrar toda a família, como por exemplo, espaços família, já incorporados a muitos shoppings, eventos para todas as idades e gêneros e até promoções que pensem em toda a família, a exemplo de pacotes de viagens.

Sendo assim, é importante que os shoppings reservem espaços de socialização de qualidade para estas ocasiões, que sejam espaçosos, com boa climatização, poltronas ou cadeiras confortáveis e até serviços-extra como totens carregadores e espaços para pets, que hoje podem ser vistos como membros da família. 
"Vejo o shopping como uma forma de lazer, porque ao mesmo tempo que vou pra comprar, vou pra ter momentos de confraternização. Como não tenho muito tempo para viajar com a família, ir ao shopping se torna um momento de lazer da família, através do cinema, dos restaurantes e dos eventos. É também uma forma segura de fazer tudo isso." (E1)

"O shopping é um lugar muito acessível e confortável para passear e até para estar presente com os meus amigos e familiares, que eu não consigo ver durante a semana." (E5)

\subsection{Shopping Ideal}

No geral, as entrevistas confirmaram que a experiência no processo de compra leva o consumidor a ter um envolvimento emocional mais elevado com o produto ou serviço (HIRSCHMAN; HOLBROOK, 1982), já que a geração Z hoje espera mais do que o básico no processo de compra.

Poucos entrevistados descreveram o shopping ideal pontuando apenas as características já existentes nestes empreendimentos hoje, como: cinema, teatro, boas lojas e restaurantes. Falando sobre cinema, os jovens esperam que as novidades de filmes cheguem de forma rápida, em linha com a velocidade esperada por esta geração, característica já levantada por Tapscott (2010). Para as lojas, a expectativa é de que o shopping tenha as lojas-âncora de vestuário: Renner, C\&A, Leader, entre outras. E, como restaurantes, esperam que tenha no mínimo as redes de fast-food mais conhecidas no país: McDonalds, Bobs e Burger King.

"Um bom shopping tem que ter um bom cinema ou um bom teatro, com uma boa oferta de filme, uma boa rotatividade de filmes." (E3)

"Tem que ter as lojas mais famosas de roupa, Renner, C\&A, Leader, restaurantes legais, cinema com filmes que mudam com uma boa frequência." (E8)

Foram mencionadas também atividades e serviços inusitados, trazendo à tona a característica de foco em inovação apresentada por Wood (2013, apud PUIU, 2016) e Tapscott (2010). Isso significa que os jovens sabem das novidades do mercado e querem testar antes dos outros, além de desejarem produtos e 
serviços inovadores e modernos por contribuir para seu status social e para sua autoimagem positiva.

Neste caso, apareceram desejos já levantados por Werneck (2017): wifi gratuito e de qualidade, games interativos e experiências com realidade aumentada e virtual. Novas tecnologias interativas foram mencionadas como uma forma de tornar a experiência do consumidor mais interessante e prazerosa, bem como mais conveniente e prática.

"O shopping ideal deveria ter um cinema com óculos de realidade virtual e muitas tecnologias inovadoras que permitissem uma experiência sensorial dentro do espaço." (E12)

"O shopping ideal teria um espelho tecnológico em cada loja que funcionaria como um provador digital de roupas sem que o cliente precisasse trocar de roupa de fato. Isso ia poupar muito o tempo das pessoas, além de ajudar a loja a ficar mais organizada sem tantas roupas jogadas nos provadores."

Além das expectativas desta geração já levantadas por Werneck (2017), foi levantado o desejo de experimentar eventos com a presença de influenciadores digitais, reforçando o poder de engajamento que as mídias sociais têm na vida destes jovens, como já havia sido apurado na pesquisa de NIRSA realizada em 2013 (PUIU, 2016):

"Espero que tenha mais eventos com influenciadores, youtubers e pessoas famosas. Pode ser pelos shows, apresentações, shooting de fotos... Até porque estes influenciadores sempre vestem looks legais e poderiam mostrar onde eles compram suas roupas, acessórios e produtos favoritos." (E4)

Apesar do poder das mídias sociais, destaca-se também a preferência por áreas que proporcionem experiências reais dentro dos shoppings, através de espaços de socialização e convivência, ambientes verdes, arborizados e com iluminação natural, remetendo a natureza, espaços para levar animais de estimação, pista para andar de skate e uma biblioteca com livros físicos. Este tipo de experiência já havia sido levantado pela pesquisa realizada pela ABRASCE (2017). 
"O shopping ideal teria uma praça aberta onde poderia ser permitido andar de skate, patins, bike e é claro, com algumas rampas para fazer as manobras." (E11)

"O shopping ideal teria um espaço aberto bem amplo, bons restaurantes com música ao vivo, um espaço para levar os pets e mais verde na decoração. Teria também um lounge de convivência com pallets, wifi funcionando, café, uma TV, música, uma biblioteca com livros disponíveis para ler no local."

Alinhado a tendência de gastronomia, levantou-se também o desejo por eventos com foodtrucks, barracas de comida e bebida. Esta experiência gastronômica pode vir acompanhada de mini shows. Ambas as tendências já haviam aparecido na pesquisa do "Shopping do Futuro" da consultoria de tendências WGSN em 2016 (FOCUS, 2017). Outro espaço físico de interesse levantado foi o rooftop, como sendo um local diferenciado que abrigue eventos com shows, curadoria, espaços para descanso e convivência.

Os depoimentos dos entrevistados apontam cada vez mais para importância de os shoppings deixarem de ser um centro de compras e centrarem suas estratégias de marketing em serviços, ações e eventos que os posicionem como um hub de entretenimento e lazer local. Percebe-se, portanto, cada vez mais a necessidade de incorporar mais lojas-conceito e espaços de entretenimento e convivência em detrimento de lojas tradicionais. Exemplos de espaços de entretenimento para estes jovens podem ser ilustrados nas citações abaixo:

"Poderia ter mais eventos com Foodtrucks ou barraquinhas de cervejas artesanais e comidinhas. Em termos de lojas, o shopping Tijuca já me atende muito bem." (E6)

"Talvez se tivesse um pub legal ou bar diferente eu viria mais. Mas, acabo vindo muito mais quando preciso comprar alguma coisa ou resolver algo. Porque pra mim lazer, está atrelado a música, beber uma cerveja. No evento que teve aqui, o Highline, eu achei bem legal por ser na área do estacionamento, com musica ao vivo e num ambiente aberto com várias opções boas de comida, bebida... Ai foi bem legal."(E7) 
"É um shopping com lojas para todos os gostos, de boa qualidade, bons filmes no cinema, uma alameda gourmet com restaurantes de todos os tipos de culinária e um rooftop que tenha eventos diferenciados (feirinhas com marcas autônomas, foodtrucks, shows, decoração moderna e colorida, locais para sentar)." (E15).

Apesar de Jennings (2017) afirmar que esta geração valoriza a privacidade e que ela se reflete também no ambiente de trabalho, as entrevistas apontaram para uma postura mais colaborativa de trabalho, alinhado a característica mencionada por Tapscott (2010). Isso porque foi levantado o desejo por espaços de convivência e trabalho em conjunto, como é o caso do coworking. Sendo assim, não se confirmou que os Zs buscam escritórios particulares, mas sim locais de trabalho conjuntos.

"Acho que poderia ter um espaço de convivência com lugar pra estudar ou trabalhar, tipo um coworking. Sinto falta disso porque a biblioteca da PUC fica cheia em período de provas e tem que sempre deixar tudo no locker, o que me incomoda um pouco. Eu queria poder estudar num ambiente um pouco diferente." (E7)

Portanto, é possível afirmar que o shopping ideal para a geração Z transcende o conceito de centro de compras com marcas tradicionais. Este novo espaço entra em um conceito de "family entertainment center", e mais do que um centro de entretenimento para a família, a expectativa sobre sua infraestrutura é de oferecer espaços alternativos para os clientes se relacionarem, se divertirem e até mesmo estudarem e trabalharem (através dos espaços colaborativos de coworking). Sendo assim, o shopping deve aproveitar sua localização (geralmente nos grandes centros urbanos e residenciais) e segurança para tornar-se o destino favorito destes jovens, seja para fazer compras, estudar, resolver problemas, encontrar pessoas, se divertir, ter experiências culturais e gastronômicas. Assim, o shopping simbolizará uma transposição de espaços que atendam as diversas necessidades destes consumidores exigentes e multitarefas, como Jennings (2017) já os havia caracterizado. 


\section{Conclusões}

O presente estudo teve como objetivo investigar o comportamento de consumo da geração $Z$ através de um estudo exploratório sobre as expectativas e preferências destes consumidores em relação a experiências de consumo e entretenimento nos shoppings centers.

A partir da criação de sete categorias de análise, a pesquisa qualitativa permitiu o levantamento do que os consumidores da geração $Z$ consideram como ideal no shopping, além de suas expectativas com relação a esta experiência. $O$ resultado sugere que a percepção deste empreendimento varia de acordo com a Zona em que mora o jovem, consequência da sua renda, afetando as suas preferências de lazer e entretenimento. Além disso, foram identificados dois grupos potencialmente distintos de frequentadores $Z$ através de suas motivações: o grupo que o frequenta pela praticidade e conveniência atreladas a uma experiência agradável; e o cliente que tem motivações hedônicas, utilitárias e sociais de forma conjunta ao visitar estes empreendimentos.

Os resultados da pesquisa sugerem que a carência de programas de lazer indoor no Rio de Janeiro leva os jovens aos shoppings, principalmente considerando que a segurança é um dos pontos mais importantes para este público na pesquisa. $E$, ao mesmo tempo que esta carência de programas de lazer e entretenimento atrai os jovens para os shoppings, estes sentem falta de aspectos ligados as suas preferências geracionais de foco em inovação, experiência, velocidade e customização.

Com isso, os resultados da pesquisa sugerem que o comportamento destes jovens no Rio de Janeiro segue o mesmo comportamento levantado por Rubens (2003 apud CERETTA e FROEMMING, 2011) no Brasil: os brasileiros de hoje priorizam o lazer e entretenimento em detrimento do consumo. As tendências mais aparentes identificadas na pesquisa foram: gastronomia, através das alamedas gourmet e eventos com foodtrucks; ambientes abertos e verdes, onde seja possível interagir com as pessoas e pets, ouvir música e experimentar eventos culturais; e tecnologia embutida na experiência, desde a exigência de um wifi de qualidade até videogames, espelhos tecnológicos e eventos com realidade virtual e aumentada. Esta última tendência confirma o que já havia sido constatado 
por Puiu (2016): eles são muito influenciados pela tecnologia, passando grande parte do seu tempo online e fazendo uso de produtos de última geração.

Portanto, percebe-se que talvez a indústria de shoppings no Rio de Janeiro não esteja suprindo as necessidades dessa geração transformacional, que espera muito mais desses centros em termos de experiência. Apesar de estes jovens serem muito ligados a tecnologia, esperam também experiências físicas memoráveis, que possam superar a realidade virtual a qual já estão acostumados. Nesse sentido, abre-se uma frente de mudanças para adaptação desta indústria a estes novos consumidores que já apresentam elevada representatividade na economia do país.

Por fim, o resultado da pesquisa sugere também implicações que as empresas inseridas na indústria de shoppings e marcas de varejo podem considerar para aprimorar a experiência para os novos consumidores, contribuindo para a conversão em vendas e força da marca.

\subsection{Sugestão para pesquisas futuras}

O campo de estudos referente à experiência em shopping center é vasto, portanto é indicado investigar mais a fundo as tendências que foram destaque na pesquisa entre os jovens da Geração Z: gastronomia, ambientes abertos e verdes e tecnologia embutida na experiência. Uma sugestão seria fazer uma pesquisa também qualitativa mais profunda acerca do que os jovens esperam de cada uma destas tendências mencionadas.

Além disso, sugere-se trabalhar com uma amostra maior e mais representativa, já que não foi possível tirar conclusões definitivas com o tamanho de amostra trabalhado.

Por fim, uma pesquisa quantitativa seria indicada para que se pudesse tanto testar as hipóteses aqui levantadas, quando avaliar a influência e a importância das variáveis que afetam a experiência em shopping, trazendo conclusões mais assertivas. 


\section{Referências Bibliográficas}

ALBUQUERQUE, F.; MALDONADO, M.; NUNES, M.; ALMEIDA, S. Prazer em Não Consumir: Motivações Hedônicas de Consumidores em Experiências de Não Compra. IV Encontro de Marketing da ANPAD, mai. 2010.

ABRASCE. Sobre a Abrasce. Disponível em < https://www.abrasce.com.br/sobre-a-abrasce/ > Acesso em 27 de nov. de 2017.

ABRASCE. Números do setor. Disponível em < https://www.abrasce.com.br/monitoramento> Acesso em 02 de jun. 2018.

BERKOWITZ, Eric N.; KERIN, Roger A.; HARTLEY, Steven W.; RUDELIUS, William. Marketing. Vol. 2. Rio de Janeiro: LTC, 2003.

BLAKLEY, C. Marketing to Generation Z starts by unlearning traditional marketing principles. Brian Solis, São Fransciso, 10 jun. de 2016. Disponível em: <http://www.briansolis.com/2016/06/marketing-generation-z-starts-unlearningtraditional-marketing-principles/> Acesso em 01 de mar. 2018.

BLOCH, P.; RIDGWAY, N.; DAWSON, S. The shopping mall as consumer habitat. Journal of Retailing, v. 70, n. 1, p. 23-42, 1994.

BRETAS, V. Os números que traduzem o perfil dos jovens brasileiros. Revista EXAME online, Editora Abril, São Paulo, 12 dez. 2016. Disponível em: $<$ https://exame.abril.com.br/brasil/os-numeros-que-traduzem-o-perfil-dos-jovensbrasileiros/> Acesso em 04 de mai. 2018.

CERETTA, S; FROEMMING, L. Geração Z: Compreendendo os hábitos de consumo da geração emergente. 2011. $10 f$.

CORRÊA, M. Brasil é o 10ำ país mais desigual do mundo. Jornal O Globo Online, 21 mar. 2017. Disponível em< https://oglobo.globo.com/economia/brasilo-10-pais-mais-desigual-do-mundo-21094828> Acesso em 02 de mai. 2018. 
CUTAIT, Michel. A evolução das necessidades do consumidor. Make it Work. São Paulo: 14 nov. 2015. Disponível em <http://makeitwork.com.br/blog/semcategoria/a-evolucao-das-necessidades-do-consumidor/> Acesso em: 02 dez. 2017.

DEARO, G. 9 números reveladores sobre os consumidores nos shoppings. Revista EXAME online, Editora Abril, São Paulo, 13 set. 2016. Disponível em: $<$ https://exame.abril.com.br/marketing/9-numeros-reveladores-sobre-osconsumidores-nos-shoppings/> Acesso em 02 dez. 2017.

DEPEC. Varejo. Mai. 2018. Bradesco. Disponível em: <https://www.economiaemdia.com.br/EconomiaEmDia/pdf/infset_varejo.pdf> Acesso em 02 de jun. 2018.

FOCUS. O que a geração Z quer de um shopping. 12 nov. de 2017. Disponível em <http://www.focus.jor.br/economia/o-que-geracao-z-quer-de-um-shopping/> Acesso em 19 abr. 2018.

FRANÇA, V. Oscar Freire atrai lojas-conceito. Jornal Online Estadão. Disponível em <https://brasil.estadao.com.br/noticias/geral,oscar-freire-atrailojas-conceito,433578> Acesso em 15 mai. 2018

HAVAS PEOPLE. Marketing to Generation Z: 6 tips to market to Generation Z. E-book Disponível em <http://www.havaspeople.com/media/1104/nc-mkgeneration-z-education-e-book-final.pdf> Acesso em 20 mar. 2018.

HOR-MEYLL, L.; FIGUEIRA, C. Motivação hedônica ou utilitária: efeitos sobre o arrependimento pós-compra. Dissertação de Mestrado. Dissertação apresentada ao Programa de Pós- graduação em Administração de Empresas da PUC- Rio como requisito parcial para obtenção do título de Mestre em Administração de Empresas. Dez. 2013.

JENNINGS, J. GENERATION Z: TWO BILLION PEOPLE COMING OF AGE. Business Today. 10 Mai. 2017. Disponível em: < http://businesstoday.co.om/Issues/Top-companies-on-MSM/Generation-Z-Twobillion-people-coming-of-age> Acesso em: 17 abr. 2018 
KOJIKOVSKI, G. Os millennials, lamentamos informar, são coisa do passado. Exame online. São Paulo, Editora Abril, 30 de nov. de 2017. Disponível em: $<$ https://exame.abril.com.br/revista-exame/os-millennials-lamentamos-informarsao-coisa-do-passado/> Aceso em 19 abr. 2018.

KOTLER, P.; KELLER, K.L. Administração de Marketing. 12. Edição. São Paulo, Pearson Prentice Hall, 2013.

LEVY, Michael; WEITZ, Barton A. Administração de Varejo. São Paulo: Atlas, 2000 .

MATOSO, F. Em 79익 lugar, Brasil estaciona no ranking de desenvolvimento humano da ONU. Revista O Globo online, 21 mar. 2017. Disponível em: $<$ https://g1.globo.com/mundo/noticia/em-79-lugar-brasil-estaciona-no-ranking-dedesenvolvimento-humano-da-onu.ghtml> Acesso em 23 mai 2018.

MEIR, J. O Trabalho vai ficar mais divertido. A geração $Z$ está chegando! Portal Online No Varejo, Grupo Padrão, Mar. 2018. Disponível em: <http://www.portalnovarejo.com.br/2018/03/13/trabalho-divertido-geracao-z/> Acesso em 18 mai 2018.

MENDONÇA, C. O que a geração Z quer das lojas dos shoppings. No Varejo. 20 jan. 2017. Disponível em: <http://www.portalnovarejo.com.br/2017/01/20/oque-geracao-z-quer-das-lojas-dos-shoppings/ > Acesso em 02 dez. 2017

Mercado\&Consumo. Shoppings investem em projetos para atrair a Geração Z. São Paulo: Grupo GS\& Gouvêa de Souza, 27 abr. 2017. Disponível em: <http://www.mercadoeconsumo.com.br/2017/04/27/shoppings-investem-emprojetos-para-atrair-a-geracao-z/> Acesso em 30 nov. 2017.

Mercado\&Consumo. Um olhar sobre o mercado de shopping center no Brasil. São Paulo: Grupo GS\& Gouvêa de Souza, 28 fev. 2014. Disponível em: <http://www.mercadoeconsumo.com.br/2014/02/28/um-olhar-sobre-o-mercadode-shopping-center-brasil/> Acesso em 02 dez.2017

MOTTA, P. C. Serviços: pesquisando a satisfação do consumidor. Rio de Janeiro: Papel Virtual, 1999. 
Mundo do Marketing. O que a Geração Z espera dos shoppings centers. Disponível em $<$ https://www.mundodomarketing.com.br/inteligencia/pesquisas/529/o-que-ageracao-z-espera-dos-shopping-centers.html> Acesso em 15 mar. 2018.

NOVAES, V. Estudo mostra como conquistar a geração Z. Revista PROPMARK online, 21 dez. 2015. Disponível em: < http://propmark.com.br/mercado/estudo-mostra-como-conquistar-a-geracao-z> Acesso em 04 mai. 2018.

OLIVEIRA, P. Shoppings investem em projetos para atrair a Geração Z. Mundo do Marketing, 24 abr. 2017. Disponível em < https://www.mundodomarketing.com.br/ultimas-noticias/37301/shoppingsinvestem-em-projetos-para-atrair-a-geracao-z.html> Acesso em 03 abr. 2018.

O NEGÓCIO DO VAREJO. Geração Z revela como quer lojas dos shoppings. Disponível em <http://onegociodovarejo.com.br/geracao-z-revela-como-querlojas-dos-shoppings/> Acesso em 30 nov. 2017.

Pantano E., e Naccarato G., (2010), “Entertainment in retailing: The influences of advanced technologies". Journal of Retailing and consumer services 17: 200 204.

PUC-RS. Pesquisa analisa crise econômica e política na vida dos jovens. Blog da Universidade PUC-RS, 08/01/2018. Disponível em $<$ http://www.pucrs.br/blog/pesquisa-analisa-crise-economica-e-politica-na-vidados-jovens/> Acesso em 10 mar. 2018.

PUIU, S. GENERATION Z - A NEW TYPE OF CONSUMERS. Young Economists Journal / Revista Tinerilor Economisti. 13, 27, 67-78, Nov. 2016.

SAWAIA, J. Gerações Y e Z: Juventude Digital. Apresentação dos resultados da pesquisa do Target Gruoup Index, IBOPE Mídia. 2010. Disponível em: <http://www4.ibope.com.br/download/geracoes\%20_y_e_z_divulgacao.pdf.> Acesso em: 19 abr. 2018.

SCHEWE, C.; MEREDITH, G.; NOBLE, S. Defining moments: Segmenting by Cohorts. American Marketing Association, 2000. 
SCHEWE, C; MEREDITH, G. "Segmenting Global Markets by Generational Cohorts: Determining Motivations by Age." Journal of Consumer Behaviour 4 (1): 51-63, 2004.

SCHIFFMAN, Leon G.; KANUK, Leslie Lazar. Comportamento do consumidor. Rio de Janeiro: LTC, 2000.

SEMME GROUP. História dos shoppings centers no Brasil. São Paulo, 26 ago. 2012. Disponível em <http://www.semma.com.br/historia-dos-shopping-centersno-brasil/> Acesso em 30 nov. 2017.

TAPSCOTT, Don. A hora da geração digital: como os jovens que cresceram usando a internet estão mudando tudo, das empresas aos governos. Rio de Janeiro: Agir Negócios, 2010.

TRENDS EMAGAZINE. Generation Z Gets Serious About Consumption. 2017. Audio-Tech Business Book Summaries, Inc.

Varejista. Pesquisa revela mudança em hábitos de compra do brasileiro. Portal Varejista, 10 mar. 2017. Disponível em <http://www.varejista.com.br/noticias/4146/pesquisa-revela-mudanca-emhabitos-de-compra-do-brasileiro> Acesso em 06 dez. 2017.

VILLAS BOAS, B. Desigualdade de renda cai no Sudeste, mas cresce no restante do Brasil. Jornal Valor Econômico Online, 11 abr. 2018. Disponível em: <http://www.valor.com.br/brasil/5444671/desigualdade-de-renda-cai-no-sudestemas-cresce-no-restante-do-brasil> Acesso em 04 mai. 2018.

WERNECK, T. O Shopping que o brasileiro quer. ABRASCE. 04 de out. 2016. Disponível em <https://www.abrasce.com.br/noticia/2690> Acesso em 06 dez. 2017.

ZIKMUND, William G.; BABIN, Barry J.; Princípios da Pesquisa de Marketing. 2. ed. São Paulo: Cengage Learning, 2010. 508 p. 
7 Anexo: Roteiro para a entrevista em profundidade:

\section{APRESENTAÇÃO:}

\section{PERGUNTAS DE FILTRO:}

1. Idade (SE FOR FORA DA FAIXA DE 17 A 24, AGRADECER E ENCERRAR)

2. Costuma frequentar shoppings? (SE NÃO, RARAMENTE, TAMBÉM DESCARTAR)

3. Mora na cidade do Rio (SE NÃO, DESCARTAR - DADO QUE VOCÊ ESTÁ FAZENDO DELIMITADA À CIDADE, É IMPORTANTE FILTRAR ESSA TAMBÉM.)

\section{ANOTAR:}

4. Gênero

5. Local de abordagem: (SHOPPING? QUAL? RUA? QUAL?)

\section{PERGUNTAR}

6. Ocupação:

7. Estuda? O quê?

8. Onde mora? (PARA SABER SE ESTÁ PRÓXIMO DE CASA, POR EXEMPLO)

\section{LAZER E SHOPPING:}

9. O que você costuma fazer nas horas vagas / como atividade de lazer?

10. Você acredita que existem opções suficientes de lazer fora de casa? Quais?

11. Para você, vir ao Shopping é uma forma de lazer? Por quê?

12. Qual(is) shopping(s) você frequenta? Com qual frequência?

13. Em que momento você frequenta estes shoppings? Ex.: finais de semana, férias, dias de semana.

\section{A EXPERIÊNCIA NO SHOPPING:}

14. Para que finalidade você vai a este(s) shopping(s)? Ex.: compras, cinema, restaurante. 
15. Qual a razão para frequentar este shopping especificamente?

- Localização,

- Mix de lojas (qualidade, variedade, exclusividade, acesso)

- Ambiente (decoração, iluminação, música, temperatura,)

- Eventos e promoções,

- Estrutura (wifi, estacionamento, restaurantes, serviços,)

- Segurança

- Ambiente social (pessoas que frequentam, amigos, conhecidos,)

- Preços

16. É o seu preferido?

- Por quê?

- $\quad$ Ou por quê não? Qual seria?

17. O que acha das pessoas que frequentam o shopping?

18. O que você gosta nos shoppings que frequenta?

19. O que você não gosta nos shoppings que frequenta? O que falta?

20. Para você, o que é a experiência de ir a um shopping?

- $\quad$ Como é? / Por quê?

- $\quad$ O que você espera de um shopping? Qual seria o shopping ideal?

21. É um lugar para... (peça para completar a frase)

- Fazer compras,

- Para passear e se divertir,

- Para socializar, encontrar as pessoas,

- Outro?

22. O que você acha do ambiente físico dos shoppings? O que te agrada mais?

- Que características são mais atrativas na sua opinião?

23. Que tipo de serviço, loja ou experiência você sente falta no shopping? Ou gostaria de ver?

24. Você já passou por uma experiência memorável em uma loja/shopping? Se sim, pode contar?

25. Você já passou por uma experiência desagradável em uma loja/shopping? Se sim, pode contar?

26. Vou ler algumas poucas frases e quero saber o quanto você concorda com elas /o quanto elas definem como é a sua experiência no shopping:

- É um ambiente em que me sinto tentado a comprar.

- Me desconecto do mundo lá fora. 
- É um lugar para encontrar pessoas e ver gente.

- É um lugar que eu gosto de passar tempo passeando.

- Só vou quando não tenho escolha.

- Eu gosto de visitar para conhecer lojas, produtos e novidades em geral. 